\title{
Applications of Tea (Camellia sinensis) and Its Active Constituents in Cosmetics
}

\author{
Wojciech Koch ${ }^{1, *}{ }^{\mathbb{D}}$, Justyna Zagórska ${ }^{2}$, Zbigniew Marzec ${ }^{1}$ and Wirginia Kukula-Koch ${ }^{2}$ (i) \\ 1 Chair and Department of Food and Nutrition, Medical University of Lublin, 4a, Chodźki str., 20-093 Lublin, \\ Poland; zbigniew.marzec@umlub.pl \\ 2 Chair and Department of Pharmacognosy, Medical University of Lublin, 1 Chodźki str., 20-093 Lublin, \\ Poland; zagorska.justyna@gmail.com (J.Z.); virginia.kukula@gmail.com (W.K.-K.) \\ * Correspondence: kochw@interia.pl; Tel.: +48-814487143
}

Academic Editor: Saverio Bettuzzi

Received: 8 November 2019; Accepted: 22 November 2019; Published: 24 November 2019

\begin{abstract}
Studies on the cosmetic applications of plant extracts are increasingly appearing in the scientific literature, which is due to the growing popularity of skincare products around the world. In the light of the observed changes, a return to natural treatment and skincare with cosmetics free of harmful substances or toxic preservatives is visible. Currently, tea extracts, due to their rich composition and various biological actions, play an important role among the dietary supplements and cosmetics. This review is intended to collect the reports on the properties of the tea plant, its extracts and preparations in cosmetology: for skin care products and for the treatment of selected dermatological diseases. Particular attention is paid to its antioxidant, anti-hyaluronidase, anti-inflammatory, slimming, hair-strengthening, photoprotective and sealing blood vessels properties.
\end{abstract}

Keywords: tea plant; skin care cosmetics; dermatology; Camellia sinensis (L.) Kuntze; catechins; Theaceae

\section{Introduction}

Cosmetics market continues to grow globally within the last decade. The growth of the upper middle class, an increasing number of senior citizens around the world and the expansion of online beauty spending and social networks, which certainly set new trends among the consumers, are all having an impact on an increasing interest in skin care products. Natural products as the cosmetics' ingredients are often associated with safety, marked activity and good quality. That is why a great interest in cosmetic products of natural origin can be observed [1].

Tea plant itself and its extracts together with their centuries-old tradition of use play an important role on the cosmetics market. In general, cosmetics products containing tea extracts rich in polyphenols have a positive effect on the skin appearance and ameliorate skin damage, erythema and lipid peroxidation following UV exposure [2]. An increasing number of cosmetics containing tea extracts, especially those produced using green tea infusions, but recently also black and white teas, encourage the authors to provide a review, that is focused on the application of tea in cosmetics. For the moment only a few review publications undertake the topic, however, the majority of them were published more than a decade ago. Due to this fact the authors found it necessary to prepare a more up-to-date manuscript that includes the information that have been spread in recent years, in the times of a constant and significant growth of the cosmetic industry [2-4]. Some of the above mentioned previously published references were also focused on the treatment of specific skin diseases only and represent rather dermatology than cosmetic applications $[5,6]$, or they described the activity of specific tea ingredients, e.g., caffeine [7] than the extracts per se. Therefore the aim of the present review is to 
collect the reports on the properties of the tea plant, its extracts and preparations in cosmetology: for skin care products and for the treatment of selected dermatological diseases.

\section{The Chemical Composition of Tea Plant (Camellia sinensis (L.) Kuntze)}

Tea plant is a rich source of bioactive components. According to the scientific literature it contains almost 4000 metabolites, among which the group of polyphenols constitutes a more than one-third share [8]. Tea infusions deliver approx. 2-3\% flavonol glycosides (kaempferol, myricetin and quercetin), whereas their aglycones most often remain in the plant matrix upon water extraction due to their lower polarity. The flavanols present in tea infusions, also called catechins, constitute as much as $20-30 \%$ of tea's dry matter. They are responsible for its taste: bitterness and astringency [9]. The composition of tea varies depending on the fermentation process applied. Black tea contains (-)-epigallocatechin gallate (EGCG), (-)-gallocatechin gallate (GCG), (-)-gallocatechin (GC), (+)-catechin (C), (-)-epicatechin (EC), gallate (-)-epicatechin (ECG) and (-)-epigallocatechin (EGC) [10-12] in contrast to green tea that is rich in EGCG - present in the highest concentration, ECG, EC and EGC [13]. The differences in the composition of these two the most common types of tea is strictly related to the production process. To obtain green tea freshly harvested leaves of Camellia sinensis are treated with hot steam to prevent fermentation and are later subjected to drying. On the other hand, black tea is produced from the leaves, which are first dried, then rolled, ground and finally fermented. This is the fermentation process that induces the oxidation of polyphenols triggered by the influence of polyphenol oxidases [14]. This process results in the transformation of simple flavonoids (e.g., catechins) into more complex structures, like thearubigins (TR), theaflavins (TF) and theobrownins (TB) [10-12].

Therefore, the catechins' concentration is inversely proportional to the degree of leaf processing [15]. Their highest content was noted in green tea, then in oolong tea and in the end-in black tea, which is due to a strong fermentation process that the latter type of tea is subjected to $[10,16,17]$. On the other hand black tea is a rich source of TR and TF [16] and oolong tea-of theasinensins and other condensed phenolic compounds [18]. TR, whose molecular weight is from 700 to $40,000 \mathrm{Da}$, gives the brew of black tea a taste and a reddish-black color [19]. In contrast, theaflavins are responsible for a golden yellow color of the infusion [9]. Catechins are certainly the best studied compounds of plant origin. However, still not much is known about the chemical structures and pharmacological properties of the catechins' conjugates, as they are difficult to identify and isolate from tea leaves. Some of the theaflavins have been, however, identified in tea extracts and include: 3-3'-theaflavin digalusate (TF3), theaflavin 3-gallate (TF2B), theaflavin 3-gallate (TF2A) and theaflavin (TF1) [20].

Different types of tea are also rich sources of simple phenolic compounds (gallic acid-GA, $p$-coumaric acid and caffeic acid) and their derivatives: theogaline and chlorogenic acid [21-24]. Other compounds present in tea include purine alkaloids (theophylline, theobromine and caffeine (theine)), amino acids, theanine [25], carbohydrates, lipids (linoleic and linolenic acids), volatile compounds, pigments (carotenoids and chlorophylls), vitamins (A, C, E, K and B) and chlorophylls [26]. It also contains numerous mineral elements such as iron, zinc, sodium, magnesium, chromium, phosphorus, potassium, titanium, manganese, nickel, copper, aluminum, silver and bromine [23,27-31]. The structures of tea main catechins and theaflavins were presented in Figure 1. 

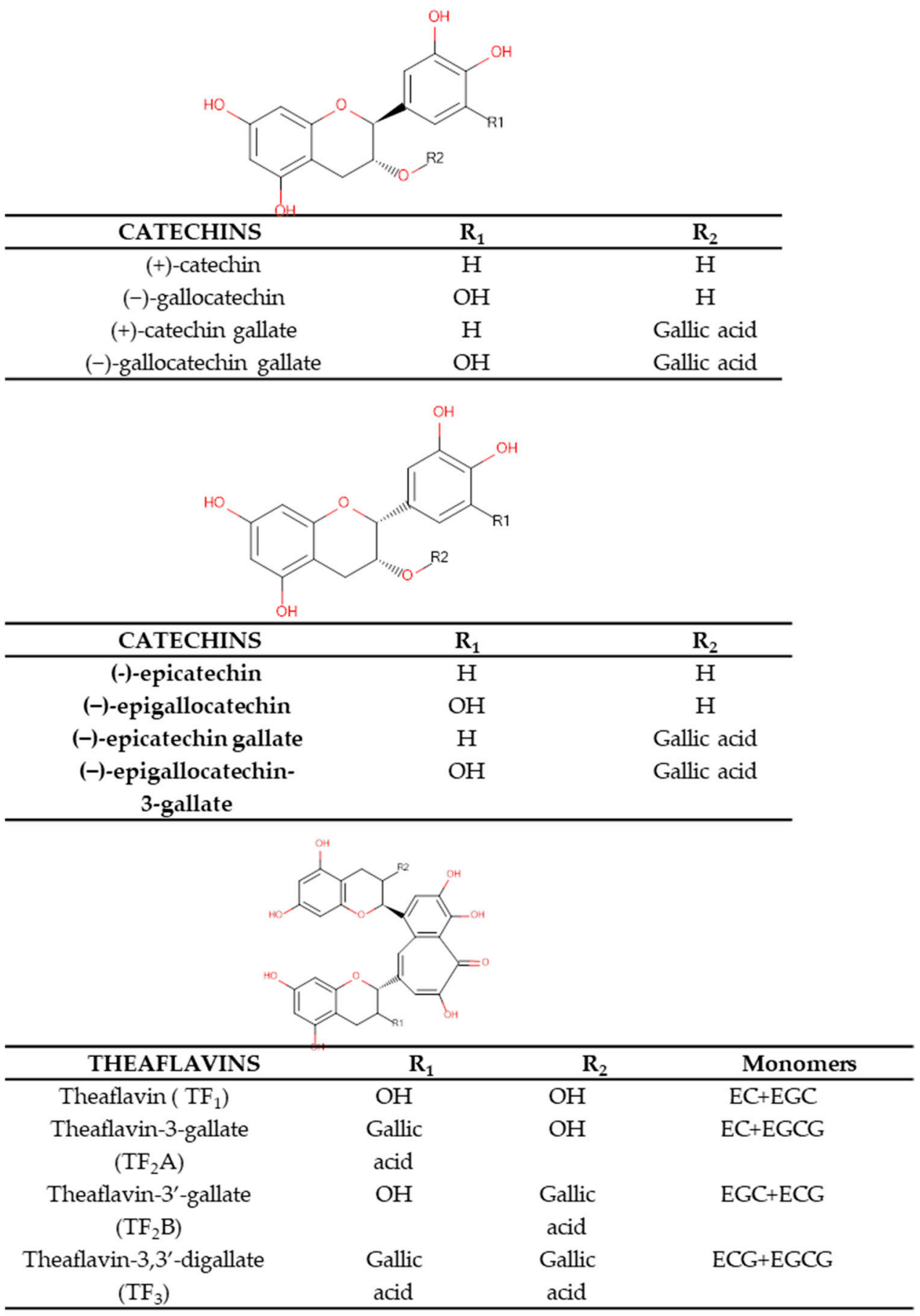

Figure 1. Chemical structures of the major secondary metabolites present in tea leaves.

\section{The Application of Tea Extracts in Cosmetics}

Tea extracts possess a wide spectrum of biological activities, which makes them precious components not only for pharmaceutical applications, but also for cosmetics industry. Among these activities antioxidant, photoprotective, anticellulite, slimming, improving skin, hair and microcirculation condition properties should be underlined (Figure 2). They will be further reviewed and discussed. 


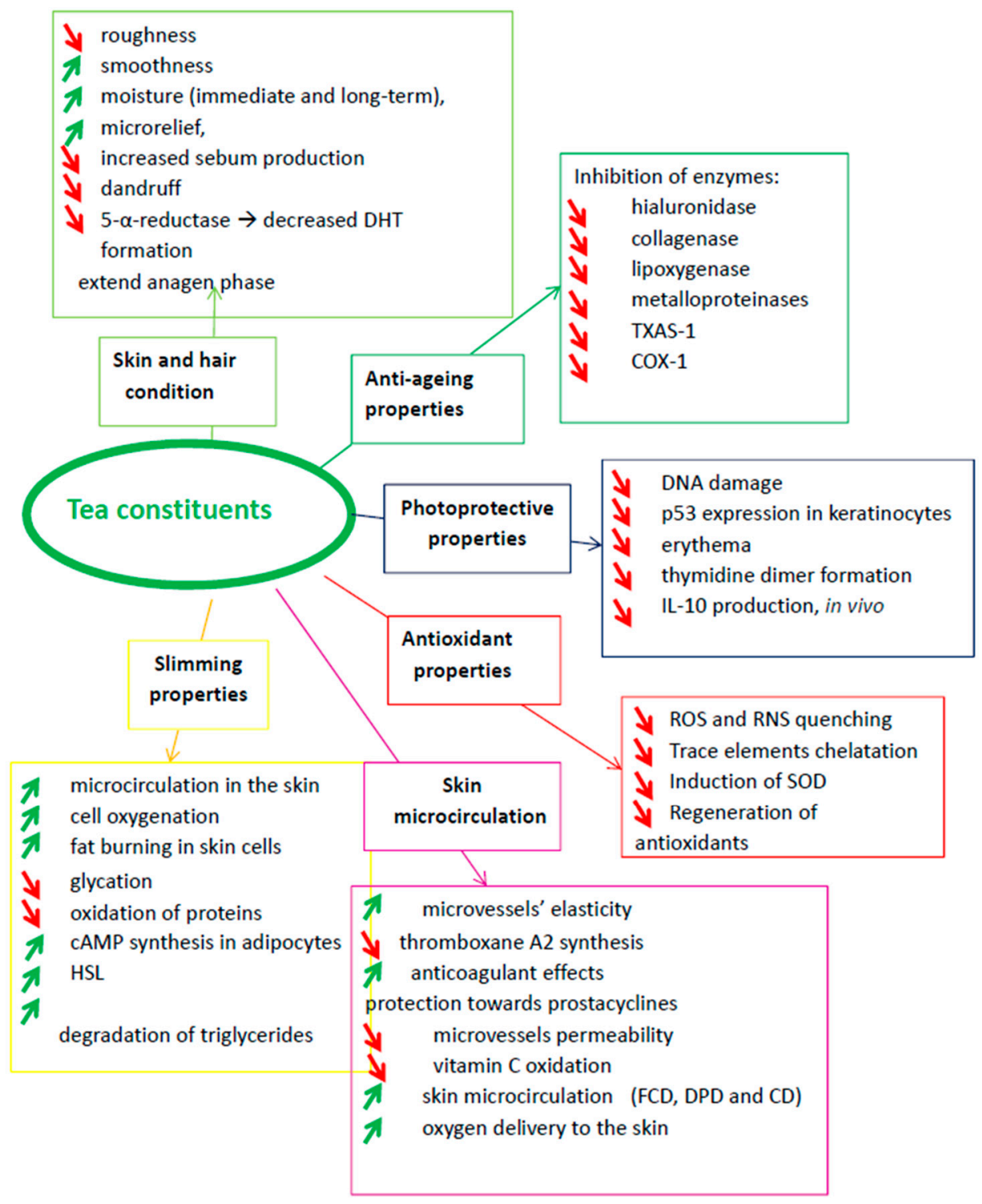

Figure 2. The major cosmetic properties of catechins ( $\boldsymbol{\lambda}_{-}$stimulation, $\boldsymbol{V}_{\text {-inhibition}) .}$

\subsection{The Application of Tea Plant in Cosmetics and its Activity for the Skin Biochemistry}

The skin is the largest organ of the human body, which accounts for approximately $15 \%$ of its weight. It is composed of three layers: the epidermis, the dermis and subcutaneous tissue [32]. The epidermis is composed mainly from two types of the cells: keratinocytes and dendritic cells. The morphology and position of the keratinocytes condition the structure of epidermis into four layers: stratum germinativum (horny cells, including the basal cell layer), stratum spinosum (the squamous cell layer), stratum granulosum (the granular cell layer) and stratum corneum (cornified or horny cell layer) [33-35]. The epidermis is a constantly renewing layer and gives rise to derivative structures, such as pilosebaceous apparatuses, nails and sweat glands. Cells from the stratum germinativum undergo proliferation cycles and continuously provide new cells for the outer epidermis. The epidermis is a dynamic layer, in which the cells are in a constant unsynchronized motion, constantly differentiating into different types of cells [35]. Each layer of the skin possesses different functions and is differently supplied with nutrients. The effects of the tea plant and its active constituents differ depending on the skin layer. In the stratum corneum, this effect is mostly due to the strong antioxidant activity of tea extracts. In deeper layers of the skin, the tea polyphenols exhibit significant protective effects against 
the ultraviolet radiation and affect the activity of various enzymes. By the inhibition of lipoxygenase, metalloproteinase, hyaluronidase and collagenase, tea and its extracts significantly delay the signs of skin aging. This is because these enzymes have a destructive effect on cellular cement lipids, such as hyaluronic acid, elastin and collagen, which are important components for the skin [35].

When administered on the dermis, these compounds improve microcirculation and the condition of blood vessels, which results in a better skin nutrition and oxygenation. Moreover, polyphenols have a protective effect towards vitamin $C$, because they prevent its oxidation. This is an important issue from a cosmetic point of view, as vitamin $C$ is involved in the synthesis of collagen, a main protein of blood vessels and skin.

Tea polyphenols also affect the sealing of blood vessels by protecting hyaluronic acid and inhibiting histamine release. Their influence on the activity of adrenaline, which contracts blood vessels, is also important. Low levels of this hormone lead to weakening of the vessels, because their contractions are then short, but frequent. The polyphenolic compounds from tea plant indirectly strengthen blood vessels, as they prevent the oxidation of adrenaline. In addition, they improve blood flow through the inhibition of platelet aggregation by different mechanisms, e.g., by hindering the thrombin proteolytic activity and inhibiting the tyrosine kinase Syk and Lyn activities [36]. According to Lee and co-investigators EGCG, the major green tea catechin, significantly inhibits cyclooxygenase (COX)-1 and thromboxane synthase (TXAS) production in platelets, which are two major enzymes responsible for the platelet aggregation. It is worth mentioning that, in the case of EGCG, this effect was even stronger as compared to a nonsteroid anti-inflammatory drug aspirin, which is commonly used to inhibit thrombotic disease-associated platelet aggregation [37].

Tea polyphenols have anti-inflammatory activity, which significantly improves skin microcirculation. This particular action is related to the radical scavenging properties of tea polyphenols, which decelerate the inflammatory processes, which disturb microcirculation and protect the intracellular cement lipids. Moreover, an inhibition of nitric oxides, prostaglandins, thromboxanes and leukotrienes, which are the main mediators of inflammation have been observed upon the administration of tea extracts [37-39].

\subsection{Antioxidant Activity}

Antioxidant properties of polyphenolic compounds are widely known and were described in numerous scientific papers [5,40-42]. Due to their specific structure, the antioxidant activity of polyphenols may be related to almost all phenolics, however, it was proved that aglycones are stronger antioxidants, compared to their corresponding glycosides [43]. All tea catechins were described as very strong antioxidant agents based on in vitro [44,45] and in vivo studies [46-49]. Table 1 shows some selected results on antioxidant properties of tea extracts in relation to other extracts used in cosmetics. A precise direct comparison of different antioxidant studies is often difficult due to a variety of antioxidant tests applied and various methodological protocols used, however, some tendencies can be observed. Taking into account that, except water, tea is the most widely consumed beverage in the world, tea catechins are considered as the most important antioxidant substances present in human $\operatorname{diet}[5,21]$. 
Table 1. The antioxidant activity assessment of some plant extracts used in cosmetics (TPC—total phenolic content, Folin-Ciocalteu method, TE-trolox equivalents, GAE—gallic acid equivalents).

\begin{tabular}{ccccc}
\hline No & Type of Extract & Antioxidant Test Applied & Antioxidant Properties & References \\
\hline 1 & Black tea & TPC & $58.2 \mathrm{mg} / 100 \mathrm{~mL}$ & {$[21]$} \\
1 & Black tea & ABTS (TE) & $3.11 \mathrm{mM} / \mathrm{L}$ & {$[21]$} \\
2 & Green tea & TPC & $97.3 \mathrm{mg} / 100 \mathrm{~mL}$ & {$[50]$} \\
3 & Green tea & ABTS $(\mathrm{TE})$ & $12.6 \mathrm{mM} / \mathrm{L}$ & {$[50]$} \\
4 & Hawthorn & DPPH & $\mathrm{IC}_{50}=48 \mu \mathrm{g} / \mathrm{ml}$ & {$[51]$} \\
5 & Chokeberry & TPC (GAE) & $0.957 \mathrm{mg} / \mathrm{mL}$ & {$[52]$} \\
6 & Grapevine (red wine) & TPC & $294.41 \mathrm{mg} / 100 \mathrm{~mL}$ & {$[53]$} \\
& Aloe & & $0.105 \mathrm{mg} / \mathrm{Ml}$ & \\
7 & gel & ABTS (IC50) & $0.033 \mathrm{mg} / \mathrm{mL}$ & {$[54]$} \\
& leaf & & $0.30 \mathrm{mg} / \mathrm{mL}$ & \\
8 & flower & TPC (GAE) & $2.12 \mathrm{mg} / \mathrm{g}$ & {$[55]$} \\
\hline
\end{tabular}

The effect of tea catechins towards the free radicals is multidirectional and includes:

- Direct quenching of reactive oxygen oxygen (ROS) and nitrogen (RNS) reactive species;

- Chelatation of trace elements that are involved in free radicals generation (e.g., copper or iron);

- Enhancement of endogenic antioxidant enzymes production (SOD (superoxide dismutase) and glutathione);

- Inhibition of enzymes involved in ROS generation (glutathione S-transferase, microsomal monooxygenase, mitochondrial succinoxidase or NADH oxidase);

- Protection and regeneration of antioxidant compounds (vitamin C or E) $[5,47,48]$.

Antioxidant properties of tea are the major and the oldest application for that cosmetics industry needs Camellia sinensis extracts. Since the discovery of free radicals theory it became obvious that free radicals can trigger chain reactions, which cause damage of biological macromolecules like proteins, lipids and nucleic acids, and as a result are very harmful to skin and mostly responsible for skin aging. Since oxidative stress is one of the most important processes determining skin ageing, natural antioxidants are considered to be the most important factors in the prevention of this process [56]. Polyphenols are able to protect and restore the content of vitamin C, which is an important co-enzyme in the production of collagen - an important protein responsible for the skin elasticity and strength, building up its structure along with elastin and keratin [34]. Different types of tea, including black, white and green, have been used to produce skin care formulations, however, the latter one due to the highest concentration of polyphenols (EGCG and EGC) can be found the most often in cosmetics formulations. Other ingredients of tea plant, like previously described vitamins, lipids and pigments could also provide additional benefits to the skin, like moisturizing and protective effects [4,57-59]. Some selected trials on the antioxidant properties of tea plant leaf extracts have been collected in the Table 2.

\subsection{Photoprotective Activity}

UV radiation (UVR; $280-400 \mathrm{~nm}$ ) may be very detrimental to the skin. There are proofs, which indicate that UVR induces skin carcinogenesis by multiple mechanisms, including direct DNA damage and indirect caused by ROS. UVR also induces cutaneous immunosuppression, potentially allowing dysplastic cells to go undetected and progress to neoplasms [60-62]. The genotoxic and cytotoxic effects of UVR in skin are well documented, and as a result malignant as well as non-melanoma skin cancers occur. In the UK there are over 40,000 of a new cases of skin cancers each year, of which $10 \%$ are malignant melanomas, with a significant risk of mortality [63]. Therefore there is a great need for searching effective photoprotective agents, with low side effects, and natural products may be very helpful to find such. 
Tea leaf extract absorbs ultraviolet radiation, due to which it protects the skin against its harmful effects. It is a component of photoprotective cosmetics for daily care [64,65]. Additionally polyphenolic compounds present in tea have strong antioxidant activity (which was reviewed above) and due to it scavenging different free radicals, which are produced during UV radiation. Tea extracts and the active compounds that they contain are increasingly applied in sunscreen cosmetics. EGCG prevents the negative effects of UV radiation on the skin, through the inhibition of collagenases, anti-inflammatory and anti-cancer properties towards the skin cells. Recent findings revealed that green tea extract should be combined with zinc oxide and titanium dioxide in sunscreen preparations. This combination increases skin protection against damage caused by UVA and UVB rays. Tea extract, alone, protects only against UVB radiation [66,67].

Recently several studies confirmed that tea and its active constituents, when taken orally or applied topically, effectively protect skin against UVR. Morley and co-investigators proved that consumption of $540 \mathrm{~mL}$ of green tea infusion significantly inhibited UVR-induced damage to peripheral blood cells. Moreover obtained in vivo data were confirmed in in vitro experiments, in which EGCG was proved to dose-dependently reduce UVR induced cells DNA damage in fibroblasts and keratinocytes cell cultures [63]. Mnich and co-investigators revealed that topical administration of a treatment lotion containing $4 \%$ green tea extract to skin patches irradiated with UVB (up to $100 \mathrm{~mJ} / \mathrm{m}^{2}$ ) significantly reduced UV-induced p53 expression in keratinocytes. The number of apoptotic keratinocytes (sunburn cells and TUNEL-positive cells-Terminal transferase dUTP-nick-end labeling assay) was also significantly decreased. On the other hand UV-induced erythema and thymidine dimer formation were also significantly affected. The authors concluded that topical application of a lotion rich in green tea extract even at low, cosmetically usable dosages efficiently reduces UVB-mediated epithelial deterioration and therefore green tea extract should be considered as suitable everyday photochemopreventive agents [68]. Not only green tea but also white tea is considered as an effective photoprotective agent. Camouse and co-workers investigated skin samples obtained from volunteers or skin explants treated with white or green tea after UV irradiation. Tea extracts were administrated topically in a special cosmetic vehicle containing deionized water, 1,3 butylene glycol, carbopol 980 triethanolamine and methyl paraben. A study was a double-blind placebo-controlled assay. The experiment revealed that application of white and green tea to a UV-irradiated skin caused a $22 \%$ and $35 \%$ reduction in CD1a+ (epidermal Langerhans cells) staining relative to unirradiated skin, respectively. Moreover, application of both teas significantly reduced oxidative DNA damage caused by UVR. As both agents were characterized by SPF 1, it was concluded that their photoprotective activity towards the skin's immune system was not connected with their direct UV absorption or a "sunscreen" effect. Additionally white tea, because of its lighter color, was considered more acceptable to use in topical preparations, especially for a regular use around the face [62].

Photoprotective effects of green tea may be strengthened when using in combination with another herbal extract. The market contains a large number of skin care formulations containing different mixtures of botanical extracts with the claim that the combination provides enhanced skin effects. However, so far few studies have confirmed their topical effect. One of the plant species studied in a combination with green tea in a cosmetic formulation was Ginkgo biloba, which was proved to significantly increase photoprotective activity of green tea extract. Topical formulation containing $6 \% \mathrm{w} / \mathrm{w}$ of each extract (green tea and Ginkgo biloba glycolic extracts) was applied to a dorsal skin of 24 male albino hairless mice (HRS/J-hairless, Jackson, Bar Harbor, ME, USA) in two different areas with $5 \mathrm{mg} / \mathrm{cm}^{2}, 15 \mathrm{~min}$ prior to UVA/UVB irradiation. The study revealed that combination of both extracts significantly decreased skin damage (dryness, irritation, presence of erythema, sunburn cell formation and epidermal hyperplasia) caused by UVR. This effect was much stronger in comparison to the application of green tea and Ginkgo biloba separately. Photoprotective activity of both herbal extracts was not due to their UV-absorption ability, but to biological effects caused in the skin, which were much stronger when both extracts were administrated together [69]. 
In general, different animal models and in vitro studies confirmed that topical treatment with green tea polyphenols reduced UVB-induced inflammatory responses, immunosuppression and oxidative stress, which may led to skin carcinogenesis (Table 2). It was also proved that external application of EGCG decreased immunosuppressive interleukin (IL)-10 production at UV irradiated skin and draining lymph nodes. Moreover, studies performed on animals revealed that topical application of green tea catechins prior to exposure to UVB protects not only against local but also systemic UVR-induced immune suppression [70].

\subsection{Anti-Cellulite and Slimming Properties}

Cellulite (gynoid lipodystrophy), often called 'orange peel effect', is a typical women's ailment, which mainly appears on the thighs and buttocks [71]. It is a complex disorder in which microcirculatory and lymphatic systems as well as extracellular matrix are involved. Increased lipolysis can be observed, which lead to increased production of diglycerides, monoglycerides, free fatty acids and glycerol. As a result excess of subcutaneous fat bulges into the dermis and forms a characteristic view, typical for cellulite. Many different hormones are involved in the lipolysis process. Adrenaline, noradrenaline, glucagon and adrenocorticotropin activate the lipases, while insulin inhibits the activity of these enzymes and stimulates the collection of fat in adipose tissue [72]. Different compounds, which activate the lipolysis pathway, stimulate structural changes of the G-protein coupled receptor and stimulate the cytosolic cAMP production. Its increasing level stimulates protein kinase A, which activates hormone-sensitive lipase (HSL) by phosphorylation. The latter enzyme hydrolyses triglycerides and its activity is cAMP-dependent $[7,73]$.

Tea, due to the content of alkaloids, is widely used in the production of cosmetics against cellulite. The major one-caffeine (known also as theine) stimulates microcirculation in the skin, which in turn improves cell oxygenation and accelerates fat burning in skin cells. Therefore, cosmetic preparations containing alcoholic or glycolic tea extracts are used to maintain a slim figure, reduce cellulite and remove toxic products from the body. Not only alkaloids, but also polyphenols, are very effective in reducing cellulite. Catechins, which are a dominant compounds present in tea extracts, were described to inhibit glycation and oxidation of proteins and thus preventing the formation of cellulite, which is one of the symptoms of skin aging. Therefore, tea is a common ingredient in cosmetic preparations with firming, slimming and anti-cellulite properties [74-76].

The main active ingredient of the tea is caffeine, which is frequently used as an anti-cellulite agent. It can be used as a pure compound or green tea extract ingredient. Caffeine could influence the mechanisms of cellulite formation in different ways. The most important is the acceleration of lipolysis through the influence on the catecholamine secretion and thus increasing the cAMP synthesis in adipocytes and activating HSL. This inhibits fat accumulation by increased degradation of triglycerides and therefore reduction of cellulite $[77,78]$.

Pires-de-Campos and co-investigators studied the effect of topical gel application with caffeine using three different models: gel with ultrasound treatment ( $3 \mathrm{MHz}$, intensity: $0.2 \mathrm{~W} / \mathrm{cm}^{2}$, rate: $\left.1 \mathrm{~min} / \mathrm{cm}^{2}\right)$, gel with caffeine (5\%, water-in-water) and gel with caffeine and ultrasound. The study was conducted using a swine hypodermis and gel was applied daily during 15 days. A specified area without any application was used as control. The study revealed that the model using caffeine and ultrasounds was the most effective. The thickness of the subcutaneous adipose tissue, damage of the adipocytes and the numbers of cells were significantly reduced [79]. Velasco and co-investigators also investigated the effectiveness of the topical application (for 21 days) of emulsion containing caffeine on the diameter and number of fatty cells using Wistar female mice. The study revealed that emulsion-containing caffeine reduced by $17 \%$ the diameter of the fatty cells [80]. Recently Byun and co-investigators evaluated the effectiveness of the slimming cream containing $3.5 \%$ of water-soluble caffeine and xanthenes for the treatment of cellulite. Fifteen subjects with cellulite applied slimming cream to the thighs and inner side of the upper arms twice daily for 6 weeks. The effectiveness was evaluated using a standard visual scale, circuit changes of the thighs and upper arms, and patient 
satisfaction using a questionnaire. Performed clinical study revealed significant improvement in skin condition and cellulite reduction (by $19.8 \%$ in the standard visual scale score). Thigh and upper arm circumferences decreased by $0.7 \mathrm{~cm}(1.7 \%)$ and $0.8 \mathrm{~cm}(2.3 \%)$, respectively, at week 6 and no serious side effects were observed [81] (Table 2).

All the above-mentioned experimental data confirm that caffeine, which is the major alkaloid present in tea leaves, is a very effective natural agent in the reduction of cellulite. When topically applied, it inhibits fat accumulation in the hypodermis and decreases the number of adipocyte cells. Therefore cosmetic formulations containing tea extracts or caffeine alone may be very efficient products in reducing skin cellulite and improving body figure.

Not only caffeine, but also tea polyphenols may be very effective in reducing cellulite and "slim" the figure. Weight reducing properties of different polyphenols, including tea catechins were recently described in numerous scientific papers [5]. Oral ingestion as well as topical application of tea extracts was described to reduce weight and decrease adipose tissue content. More than 24 clinical placebo-controlled trials, performed on obese patients, revealed that consumption of 600-900 mg of tea polyphenols per day (which is equal to 3-4 cups of green tea) significantly decreased total abdominal fat, reduced serum triglycerides, induced adipogenesis, increased energy expenditure and fat oxidation and improve fecal lipid excretion. As a result significant weight loss and reduction of skin fat tissue was observed [82-84]. In vivo studies also performed in various animal models showed that increased intake of tea extracts or its active constituents significantly decreased hepatic lipid accumulation, white adipose tissue weight and downregulated over 100 genes related to tissue inflammatory responses $[85,86]$.

Rao and co-investigators tested a cream containing black pepper, sweet orange peel, ginger root extract, cinnamon bark extract, capsaicin, green tea and caffeine. The formulation was applied under occlusion with neoprene shorts to 20 patients. After testing $76 \%$ of the volunteers noticed an overall improvement of their cellulite, with $54 \%$ reporting greater improvement in the thigh that received garment occlusion. Professional dermatological examination revealed significant improvement of the skin of the thighs condition (average circumference reduction was $1.2 \mathrm{~cm} ; 1.3 \mathrm{~cm}$ in the group with occlusion and a $1.1 \mathrm{~cm}$ reduction without occlusion) [87]. Although there are many cosmetic preparations for the treatment of cellulite, which contain different tea extracts, the literature review showed almost no studies evaluating the effectiveness of tea polyphenols in the treatment of cellulite. Their efficacy towards cellulite reduction is mostly based on their properties to treat obesity, decrease weight, reduce waist circumference and improve thermogenesis [88,89]. Therefore, there is a strong need to perform studies, which will evaluate the influence of tea polyphenols on cellulite, both orally and especially topically.

Although tea polyphenols were not studied towards their anti-cellulite activity, there are experiments that proved that products rich in polyphenols might effectively reduce cellulite. Savikin and co-investigators revealed that dietary supplementation with chokeberry juice rich in polyphenols improve skin morphology in cellulite. They examined twenty-nine women aged $25-48$ with a cellulite grade 2 according to the Nurnberger-Muller scale. All patients consumed $100 \mathrm{~mL}$ of the juice for 90 days. Skin structure was analyzed by ultrasonography at 0,45 and 90 days of the study. The study revealed significant reduction in the subcutaneous tissue thickness ( $1.9 \mathrm{~mm}$ on average). Moreover the length of subcutaneous tissue fascicles was reduced in $97 \%$ of subjects. It was also observed that in the subjects with edema at the baseline, after 45 days of treatment, it was reduced in $55.2 \%$ of patients, while after 90 days edemas were not observed in any of the individuals involved in the study. The authors did not investigate polyphenolic composition of the juices, they only performed determinations using a Folin-Ciocalteu reagent. Therefore it is difficult to state which particular polyphenols were primarily responsible for such an effect [90]. 


\subsection{Improvement of Skin Condition}

Green tea is the type of tea that is the most extensively used in cosmetic preparations improving skin and hair condition. Although an easy search for a term "green tea skin care products" allows us to find over 50 different products that can be used on skin, nails and hair. These products are targeted towards the improvement of aging skin, treating rosacea, acne, warts and increased sebum production. However after closer evaluation of the product information, it occurs that there is little information on the extract preparation, its concentration and other active ingredient content. It is generally accepted that $5 \%$ is an effective concentration of green tea extract in cosmetic formulation, however it should be remembered that catechins, being one of the most effective antioxidants, are very sensitive to light and oxygen. Therefore they require a very careful formulation to retain their biological activity. Another question is the skin permeability of catechins as these are a typical hydrophilic compounds and they penetration in human skin is limited. Thus, according to Farris, there should be a healthy dose of skepticism, for both consumers and dermatologists, regarding the effectiveness and usefulness of cosmetics containing green tea [91]. There is also little scientific data, especially clinical experiments, which support the wide use of tea extracts in cosmetics improving the condition of the skin and hair. Another question is the fact that the term "improving" is very relative and consumers may often have a big problem in proper evaluation of the cosmetic effectiveness, and their assessment may be incorrect. Only typical dermatological examination can be an appropriate tool to evaluate the efficacy of the cosmetic formulation.

A clinical study conducted by Syed and co-workers revealed an improvement in skin texture and appearance in $45 \%$ of volunteers after a 4 -week application of gel containing EGCG [92]. In another clinical study different cosmetic formulations containing vehicles supplemented with $6 \%$ Camellia sinensis glycolic leaf extracts were applied to the forearm skin of 24 volunteers. Before the study and after $2 \mathrm{~h}, 15$ and 30 days the following parameters were evaluated: stratum corneum water content, transepidermal water loss, skin viscoelastic-to-elastic ratio (Uv/Ue) and microrelief. Obtained results revealed significant increase in skin moisture (immediate and long-term), improved skin microrelief (skin texture), represented by reduced skin roughness and enhanced skin smoothness (especially after 15-30 days of treatment). It was also proved that formulations containing green tea extract after 30 days of topical administration significantly enhanced $\mathrm{Uv} / \mathrm{Ue}$ parameter in comparison to vehicle and control. The authors concluded that green tea might be a promising botanical component of cosmetics, which especially improve moisture and microrelief of the skin [42].

A clinical double-blind placebo study, sponsored by NuSkin (Provo, Utah, USA) was conducted to evaluate the efficacy of the combined oral supplementation of the green tea extract and topical application of the special cream containing $10 \%$ of green tea extract to improve the appearance of the photoaged skin [93]. The study involved 40 women with moderate photoaging. Eighteen individuals took a dietary supplement containing $300 \mathrm{mg}$ of green tea extract (twice daily) and applied two times per day a portion of green tea cream. In the placebo group 18 women took placebo supplement and placebo cream also twice per day. All the subjects used the same sunscreen and cleanser. The study was conducted for 8 weeks. After finishing, professional dermatological external examination revealed no statistical changes of the skin of the patients from both groups. However, the skin biopsy shown significant improvement in elastic tissue content in the green tea treated group. Unfortunately, the design of the study, did not allow determining of whether the obtained effect was due to the oral intake of green tea or its topical application.

Green tea based cosmetic formulations are also popular to reduce increased sebum production, which is a main feature of an oily face. Sebum is a mixture of lipids, mainly squalene and wax esters, which is produced by sebaceous glands, especially on the face and scalp. Sebum production is hormonally regulated, and its increased production causes serious skin disorders, such as acne vulgaris [6]. Topical application of green tea extract may be very beneficial in reducing excessive sebum production and two independent clinical studies proved its effectiveness. Meethama and co-workers in a randomized single-blind, placebo-controlled study proved anti-sebum efficacy of a facial tonners 
containing green tea. The developed cosmetics contained $2 \%, 4.5 \%$ and $7 \%$ of green tea extract with $100 \mathrm{mg} \%$ of polyphenols, whereas the base consisted of hydroxyethyl cellulose, glycerin and panthenol. The study involved twenty healthy Thai volunteers (sixteen female and four male) aged between 20 and 35 years old. All tested products were stable and caused no skin irritation, which was proved using patch tests. Performed clinical investigation revealed significant anti-greasy and anti-sebum activity of a green tea extract, which in both cases were positively correlated with the concentration of the extract. Moreover it was proved that the effectiveness of a 28 days treatment was significantly better than 14 days. It was stated that cosmetics containing green tea extract might effectively improve the condition of oily face [94]. In a single-blinded, placebo controlled monocentric study performed by Mahmood and co-workers, a group of twenty two non-smoker, healthy men was investigated towards the effectiveness of a lotus and green tea topical application on facial sebum production. Volunteers were divided into two groups - in a first group men used green tea (5\%) topical on one cheek and placebo control on another $(n=11)$. The second group used a combination of green tea and lotus $(2.5 \%$ each) on one cheek and placebo control on another $(n=11)$. Both groups were asked to apply their respective topicals at bedtime for 60 days. Sebum secretion was measured using sebumeter in both groups at baseline and after 15, 30, 45 and 60 days. The study revealed a significant reduction of sebum production in both groups after 60 days of treatment - in the group applying only green tea and the combination of green tea and lotus, the sebum production was reduced by $27 \%$ and $25 \%$, respectively. The performed study revealed that cosmetic therapy using green tea extract alone as well as a combination of green tea and lotus extracts may be a very effective tool in the treatment of skin disorders associated with increased sebum production, such as acne vulgaris [95]. In another study performed by Mahmood and co-workers ten healthy men aged 24-40 years old used topically to their cheeks a cosmetic formulation containing 3\% of green tea extract. The experiment was conducted for eight weeks and a sebumeter was used to evaluate the reduction in sebum production, which was then calculated to a percentage value. Obtained results revealed significant decrease in sebum production during the eight weeks study. The strongest effect was observed after eight weeks of treatment (the reduction of 60\%). However, already after the first week significant improvement was noted (10\%) [96]. It should be strongly emphasized that both of the above mentioned studies had significant limitations. A small sample size, the investigated group that involved only men and no comparison treatment or placebo control (in the case of the latter study [97]) were the biggest disadvantages of both of these studies (Table 2).

\subsection{Improvement of Hair Condition}

Cosmetic preparations containing tea extracts are recommended for patients with androgenetic alopecia and hair loss, regardless of gender. The occurrence of androgenic alopecia is directly related to the conversion of testosterone into more active dihydrotestosterone (DHT), which is mainly responsible for baldness. Hair follicles are particularly sensitive to DHT, which shortens the anagen phase of the hair growth cycle. As a result, most of the hair passes into the telogen phase, which is characterized by follicle miniaturization and reduction of hair roots. The newly growing hair is weaker-thinner and shorter and after several cycles, they stop to growth and hair loss can be observed [68]. In several studies tea polyphenols, essential oils and caffeine present in tea plant leaves inhibit the activity of $5 \alpha$-reductase, which results in a decreased DHT formation [96,98]. The former compounds were also found stimulate hair roots and extend the hair growth phase (anagen phase) [76]. Therefore, constituents of tea are important ingredients of hair and scalp care cosmetics, which are especially recommended to individuals having excessive greasy hair and dandruff $[11,74,76]$.

Fischer and co-investigators performed an in vitro study, which have shown that external application of caffeine in a concentration of $0.001 \%$ and $0.005 \%$ led to a significant stimulation of human hair follicle growth. It was concluded that caffeine reduces smooth muscle tension near the hair follicle and therefore significantly increases delivery of nutrients through the microcirculation of the papillae of the hair [98]. 
Green tea polyphenols were proved to significantly improve hair loss in mice. A group of 30 mice were fed with $50 \%$ fraction of polyphenol extract from dehydrated green tea in their drinking water for six months, whereas the control group received regular drinking water. Both groups received the same diet. The study revealed significant improvement in hair growth (33\% of animals) in comparison to control group [99]. One of the main catechins present in green tea extract-EGCG was proved to be strong $5 \alpha$-reductase and aromatase inhibitor [100,101]. This fact may significantly explain the effectiveness of using green tea polyphenols to treat androgenic alopecia, which is mainly associated with increased activity of these both enzymes. Such a mechanism was proved by Kwon and co-workers who evaluated the efficacy of EGCG on human hair growth. The study revealed that EGCG stimulated hair growth in hair follicles ex vivo culture and the proliferation of cultured human dermal papilla cells. Moreover, it was shown that epigallocatechin-3-gallate promoted hair growth in vivo dermal papillae of human scalps. It was concluded that EGCG stimulates hair growth through dual proliferative and anti-apoptotic effect [102].

All the above mentioned experiments proved practical usefulness of tea extract in formulating cosmetics, which improve skin appearance and hair condition and growth. However, majority of these studies deal with green tea extract, therefore more research regarding black or white tea application should be performed.

\subsection{Improvement of Skin Microcirculation}

It is widely known that tea polyphenols improve microvessel system and microcirculation in the skin and-through different receptors-increase microvessels elasticity [37]. Polyphenols are thromboxane A2 synthesis inhibitors, which induce the anticoagulant effect. Due to their strong antioxidant properties these compounds also have a protective activity towards prostacyclines. Their influence on microvessels permeability is also indirect as they inhibit the oxidation of vitamin $C$, which is a key factor in collagen synthesis-a protein that is a crucial component of vascular wall [38]. There are studies, which based on the above mentioned mechanisms, proved that internal and external use of tea polyphenols may significantly improve skin microcirculation [5].

Heinrich and co-investigators performed a 12-week, double-blind, placebo-controlled study, involving 60 female volunteers, who were randomized to an intervention or control group. The first group received a beverage containing green tea polyphenols providing $1402 \mathrm{mg}$ of catechins per day. The second group received a control beverage. Several skin parameters (skin photoprotection, structure and function) were measured at baseline, after 6 weeks and after 12 weeks. The study revealed significant improvement in skin deterioration following UV-radiation, elasticity, roughness, scaling, density and water homeostasis. What is important, the consumption of beverage rich in green tea catechins significantly increased blood flow ( $40 \%$ by week 6 and $29 \%$ by week 12$)$ and oxygen delivery to the skin (from $30 \%$ at the baseline up to $38 \%$ and $40 \%$ by week 6 and 12, respectively). Within the same experiment a randomized, double-blind, single-dose $(0.5,1.0$ and $2.0 \mathrm{~g})$ study of green tea polyphenols, which were administrated in a form of a capsule was performed on a group of 15 female volunteers who had not participated in the 12-week study. This short-term study showed that blood flow was maximized at $30 \mathrm{~min}$ after ingestion. In general, performed clinical investigation proved that increased intake of green tea catechins significantly improves skin condition, including blood flow and microcirculation in the skin tissue 5]. Rothenberger and co-workers investigated whether tea tree oil increases skin blood flow, which is a very important task in wound treatment. Therefore the authors analyzed the direct effect of topical antiseptic agents, including oil from a tea tree, on the microcirculation of intact human skin. The study was conducted in a group of 20 volunteers (nine men and 11 women). Patients immersed their fore, middle, ring and little fingers of the right hand in cups with appropriate solutions, including $5 \%$ of tea tree oil, which was dissolved in $0.9 \%$ of $\mathrm{NaCl}$. An oxygen to see diagnostic device was used to evaluate oxygen supply in microcirculation of blood perfused tissues (blood flow, hemoglobin oxygenation and the relative amount of hemoglobin). Obtained results showed that tea tree oil significantly increased $(+19 \%)$ blood flow compared to control. 
Moreover, the improvement after using tea tree oil was the highest in comparison to other substances used in the study (ocetnidine and polyhexanide). The alterations in the hemoglobin oxygenation were not significant. Tea was proved to be a very effective antibacterial agent, which significantly improves skin perfusion, which is an important factor in wound healing [103] (Table 2).

Caffeine was also proved to improve the microcirculation in the skin of the head and therefore to increase nutrients delivery to the hair bulbs, which strengthens and stimulates rapid growth of the hair [104]. This alkaloid was also proved to improve the circulation in other tissues. An in vivo study performed using positron emission tomography (PET) revealed that oral administration of $250 \mathrm{mg}$ of caffeine improved blood circulation in the human brain by $30 \%$ [105], whereas a dose of $100 \mathrm{mg}$ given orally increased microcirculation in the human ocular fundus, which was revealed in a study performed on 10 healthy volunteers using a laser speckle tissue circulation analyzer [106]. Lupi and co-workers performed a clinical investigation in a group of 134 women with cellulite, aged between 20 and 39 years, to evaluate the effectiveness of a commercially available cosmetic (Elancyl ${ }^{\circledR}$ Chrono-Active) composed mainly of a 7\% caffeine solution, to improve microcirculation and reduce cellulite. Microcirculatory parameters evaluated were functional capillary density (FCD; number of flowing capillaries per unit area), diameter of the dermic papilla (DPD) and capillary diameter (CD). Moreover different clinical parameters, such as centimetrical measurements of thighs and hips, were evaluated. Additionally the influence of tobacco smoking, alcohol consumption and physical activity on the efficacy of the treatment was assessed. The study was conducted for 1 month. Obtained results revealed an increase of the all microcirculation parameters (FCD, DPD and CD) in the studied group. However, the changes were not statistically significant. Thigh and hip circumferences were significantly reduced, in more than $80 \%$ and $67 \%$ of cases, respectively. Moreover, it was shown that tobacco smoking, alcohol consumption and the level of physical activity had no influence on the circumference of the treated thighs and hips [107]. Table 2 summarizes studies and their results, which were performed regarding the beneficial effects of tea and its active constituents towards the skin. 
Table 2. Beneficial effects of tea and its active constituents towards the skin-summary.

\begin{tabular}{|c|c|c|c|c|c|}
\hline \multirow{2}{*}{ Activity } & \multicolumn{2}{|c|}{ Experimental Model } & \multirow{2}{*}{ Type of Tea/Active Constituent } & \multirow{2}{*}{ Mechanism of Action/Effect } & \multirow{2}{*}{ Reference } \\
\hline & In vitro & In vivo/Ex vivo & & & \\
\hline \multirow[t]{4}{*}{ Antioxidant } & DPPH, ABTS, FRAP assays & Different animal models & Tea catechins (EC, EGCG, EGCG) & $\begin{array}{c}\text { • Direct ROS and RNS scavenging } \\
\text { - Chelation of trace elements, which are involved in } \\
\text { free radicals generation (Cu, Fe) } \\
\text { - Increasing of the endogenic antioxidant enzymes } \\
\text { production (SOD, glutathione) } \\
\text { - Inhibition of enzymes involved in ROS generation } \\
\text { (glutathione S-transferase, microsomal } \\
\text { monooxygenase, mitochondrial succinoxidase or } \\
\text { NADH oxidase) } \\
\text { - Protection and regeneration of antioxidant } \\
\text { substances (vitamin C or E) }\end{array}$ & {$[5,43,44,47,48]$} \\
\hline & & Phase II, clinical evaluation & $\begin{array}{l}\text { Topical application of gel } \\
\text { containing EGCG }\end{array}$ & $\begin{array}{l}\text { Improvement in skin texture and skin appearance in } \\
45 \% \text { of volunteers after a } 4 \text {-week application }\end{array}$ & [92] \\
\hline & & $\begin{array}{l}\text { Double-blinded, } \\
\text { placebo-controlled trial } 40 \\
\text { women with moderate } \\
\text { photoaging } 8 \text { weeks of } \\
\text { treatment }\end{array}$ & $\begin{array}{c}\text { Green tea extract } \\
\text { - oral supplementation }(300 \mathrm{mg}, 2 \\
\text { per day) } \\
\text { - topical application of } 10 \% \text { green } \\
\text { tea cream }\end{array}$ & $\begin{array}{l}\text { - Skin biopsies revealed significant improvement in the } \\
\text { elastic tissue content } \\
\text { - No clinically significant changes regarding protection } \\
\text { from cutaneous signs of photoaging were detected }\end{array}$ & [93] \\
\hline & & 24 volunteers & $\begin{array}{l}\text { Different cosmetic formulations } \\
\text { containing vehicles } \\
\text { supplemented with } 6 \% \text { Camellia } \\
\text { sinensis glycolic leaf extracts } \\
\text { Application to the forearm skin }\end{array}$ & $\begin{array}{l}\text { - Significant increase in skin moisture (immediate and } \\
\text { long-term) } \\
\text { - Improved skin microrelief (skin texture) (especially } \\
\text { after } 15-30 \text { days of treatment) } \\
\text { - Significant enhancement of the skin } \\
\text { viscoelastic-to-elastic ratio (Uv/Ue; after } 30 \text { days) }\end{array}$ & [41] \\
\hline \multirow[t]{2}{*}{ Photoprotective } & $\begin{array}{l}\text { Normal fetal lung fibroblasts } \\
\text { (MRC5) } \\
\text { Adult skin fibroblasts (84BR) } \\
\text { Normal human epidermal } \\
\text { keratinocytes (NHEK) }\end{array}$ & $\begin{array}{l}\text { Peripheral blood cells } \\
\text { obtained from10 healthy } \\
\text { non-smoking volunteers (six } \\
\text { female and four men) }\end{array}$ & $\begin{array}{l}\text { EGCG (in vitro assay) } \\
540 \text { mL of green tea infusion } \\
\text { (in vivo study) }\end{array}$ & $\begin{array}{c}\text { - Significant inhibition of UVR-induced damage to } \\
\text { peripheral blood cells } \\
\text { - Dose-dependent inhibition of the UVR-induced DNA } \\
\text { damage in fibroblasts and keratinocytes cell cultures } \\
-250 \mu \mathrm{M} \text { of EGCG was found to be optimal } \\
\text { concentration to inhibit DNA cell damage caused } \\
\text { by UVR }\end{array}$ & [63] \\
\hline & & $\begin{array}{l}21 \text { voluntary healthy } \\
\text { participants } \\
\text { Skin patches irradiated with } \\
\text { UVB (up to } 100 \mathrm{~mJ} / \mathrm{m}^{2} \text { ) }\end{array}$ & $\begin{array}{l}\text { External application of a water in } \\
\text { oil emulsion containing } 4 \% \text { of } \\
\text { green tea extract }\end{array}$ & $\begin{array}{l}\text { - Significant decrease of UV-induced p53 expression in } \\
\text { keratinocytes } \\
\text { - Significant reduction of apoptotic keratinocytes } \\
\text { - Significant reduction of the UV-induced erythema } \\
\text { and thymidine dimer formation }\end{array}$ & [72] \\
\hline
\end{tabular}


Table 2. Cont.

\begin{tabular}{|c|c|c|c|c|c|}
\hline \multirow{2}{*}{ Activity } & \multicolumn{2}{|c|}{ Experimental Model } & \multirow{2}{*}{ Type of Tea/Active Constituent } & \multirow{2}{*}{ Mechanism of Action/Effect } & \multirow{2}{*}{ Reference } \\
\hline & In vitro & In vivo/Ex vivo & & & \\
\hline & & $\begin{array}{c}\text { A double-blind } \\
\text { placebo-controlled assay } \\
\text { - } 10 \text { healthy volunteers } \\
\text { - skin explants (ex vivo study) }\end{array}$ & $\begin{array}{l}\text { White and green tea extracts } \\
\text { applied topically in a specially } \\
\text { prepared cosmetic vehiculum }\end{array}$ & $\begin{array}{l}\text { - Significant reduction of cutaneous immunity in } \\
\text { UV-irradiated skin (stronger in the case of green tea) } \\
\text { - Prevention of UV-induced oxidative DNA damage in } \\
\text { the form of 8-OHdG (8-hydroxy-2'-deoxyguanosine) }\end{array}$ & [66] \\
\hline & & $\begin{array}{l}24 \text { male albino hairless mice } \\
\text { (HRS/J-hairless, Jackson, Bar } \\
\text { Harbor, ME, USA) }\end{array}$ & $\begin{array}{c}\text { Green tea and Ginkgo biloba } \\
\text { glycolic extracts } \\
\text { Topical formulation containing } \\
6 \% \text { of each extract applied in two } \\
\text { different areas in a concentration } \\
\text { of } 5 \mathrm{mg} / \mathrm{cm}^{2}, 15 \text { min prior UV } \\
\text { irradiation }\end{array}$ & $\begin{array}{c}\text { - Significant reduction of the UV-induced skin damage } \\
\text { (dryness, irritation, presence of erythema, sunburn cell } \\
\text { formation and epidermal hyperplasia) } \\
\text { - Much stronger effect when both extracts were } \\
\text { applied together } \\
\text { - Strong photoprotective activity due to biological } \\
\text { effects caused in the skin and not photo-absorption } \\
\text { properties of both herbal extracts }\end{array}$ & [69] \\
\hline \multirow[t]{4}{*}{$\begin{array}{l}\text { Anticellulite and } \\
\text { slimming } \\
\text { properties }\end{array}$} & & $\begin{array}{l}\text { More than } 24 \text { clinical } \\
\text { placebo-controlled trials } \\
\text { performed on obese patients }\end{array}$ & $\begin{array}{l}\text { Oral ingestion of } 600-900 \mathrm{mg} \text { of } \\
\text { tea polyphenols per day } \\
\text { (equal to } 3-4 \text { cups of green tea) }\end{array}$ & $\begin{array}{c}\text { - Significant reduction of the total abdominal fat } \\
\text { - Significant reduction of the weight } \\
\text { - Significant reduction of the skin fat tissue } \\
\text { - Reduced serum triglycerides } \\
\text { - Induced adipogenesis } \\
\text { - Increased energy expenditure-increased fat oxidation } \\
\text { - Improved fecal lipid excretion }\end{array}$ & [5,82-84] \\
\hline & & Swine hypodermis & $\begin{array}{c}\text { Caffeine } \\
\text { Three models: } \\
\text { - Gel with ultrasound treatment } \\
\left(3 \mathrm{MHz} \text {, intensity: } 0.2 \mathrm{~W} / \mathrm{cm}^{2},\right. \\
\left.\text { rate: } 1 \mathrm{~min} / \mathrm{cm}^{2}\right), \\
\text { - Gel with caffeine }(5 \% \text {, } \\
\text { water-in-water }) \\
\text { - Gel with caffeine and ultrasound } \\
\text { Application during } 15 \text { days }\end{array}$ & $\begin{array}{c}\text { - Model using caffeine and ultrasound was proved to } \\
\text { be the most effective } \\
\text { - Significant reduction of the subcutaneous adipose } \\
\text { tissue, damage of the adipocytes and the numbers } \\
\text { of cells }\end{array}$ & [79] \\
\hline & & Wistar female mice & $\begin{array}{l}\text { Cosmetic emulsion containing } 4 \% \\
\text { of caffeine applied topically for } \\
21 \text { days }\end{array}$ & $\begin{array}{l}\text { - Significant reduction (by } 17 \% \text { ) of the fatty cells } \\
\text { diameter }\end{array}$ & [80] \\
\hline & & $\begin{array}{l}\text { Clinical study } \\
\text { - } 15 \text { healthy female volunteers } \\
\text { with cellulite on the thigh and } \\
\text { medial side of the upper arms }\end{array}$ & $\begin{array}{l}\text { Slimming cream containing } 3.5 \% \\
\text { of water-soluble caffeine and } \\
\text { xanthenes for the treatment } \\
\text { of cellulite } \\
\text { Topical application twice daily for } \\
6 \text { weeks }\end{array}$ & $\begin{array}{c}\text { - Significant improvement in skin condition } \\
\text { - Significant reduction of the cellulite (by } 19.8 \%) \\
\text { - Reduction of thigh }(0.7 \mathrm{~cm}-1.7 \%) \text { and upper arm } \\
(0.8 \mathrm{~cm}-2.3 \%) \text { circumferences } \\
\text { - No side effects }\end{array}$ & [81] \\
\hline
\end{tabular}


Table 2. Cont.

\begin{tabular}{|c|c|c|c|c|c|}
\hline \multirow{2}{*}{ Activity } & \multicolumn{2}{|c|}{ Experimental Model } & \multirow{2}{*}{ Type of Tea/Active Constituent } & \multirow{2}{*}{ Mechanism of Action/Effect } & \multirow{2}{*}{ Reference } \\
\hline & In vitro & In vivo/Ex vivo & & & \\
\hline & & $\begin{array}{l}\text { Double-blinded, randomized } \\
\text { trial } \\
20 \text { women with a moderate } \\
\text { degree of cellulite } \\
\text { 4-week treatment }\end{array}$ & $\begin{array}{c}\text { Anti-cellulite cream containing } \\
\text { black pepper, sweet orange peel, } \\
\text { ginger root extract, cinnamon } \\
\text { bark extract, capsaicin, green tea } \\
\text { and caffeine. } \\
\text { Topical application } \\
\text { Combination of anti-cellulite } \\
\text { cream and occlusive } \\
\text { bioceramic-coated } \\
\text { neoprene garment }\end{array}$ & $\begin{array}{c}\text { - } 76 \% \text { volunteers reported improvement of } \\
\text { their cellulite } \\
\text { - } 54 \% \text { women declared greater improvement in the } \\
\text { thigh that received garment occlusion } \\
\text { - Significant improvement of the skin of the thighs } \\
\text { condition (average circumference reduction was } \\
1.2 \mathrm{~cm} ; 1.3 \mathrm{~cm} \text { in the group with oclussion and a } 1.1 \mathrm{~cm} \\
\text { reduction without occlusion) }\end{array}$ & [87] \\
\hline & & $\begin{array}{l}29 \text { women aged } 25-48 \text { with a } \\
\text { cellulite grade } 2 \text { according to } \\
\text { the Nurnberger-Muller scale }\end{array}$ & $\begin{array}{l}\text { Dietary supplementation with } \\
\text { chokeberry juice rich in } \\
\text { polyphenols } \\
100 \mathrm{~mL} / \text { day for } 90 \text { days }\end{array}$ & $\begin{array}{l}\text { - Significant reduction in the subcutaneous tissue } \\
\text { thickness (1.9 mm on average) } \\
\text { - Length of subcutaneous tissue fascicles was reduced } \\
\text { in } 97 \% \text { of subjects } \\
\text { - Reduction of edema in } 55.2 \% \text { of patients after } 45 \text { days } \\
\text { of treatment } \\
\text { - Lack of edema in all subjects after } 90 \text { days of } \\
\text { treatment } \\
\text { - No qualitative or quantitative determinations of the } \\
\text { phenolic composition of the juices were performed }\end{array}$ & [90] \\
\hline \multirow{2}{*}{$\begin{array}{l}\text { Improvement of } \\
\text { skin and hair } \\
\text { condition }\end{array}$} & & $\begin{array}{l}\text { Clinical double-blind placebo } \\
\text { study } \\
36 \text { participants (18 in the } \\
\text { study group and } 18 \text { in the } \\
\text { placebo group) }\end{array}$ & $\begin{array}{l}\text { Dietary supplement containing } \\
300 \mathrm{mg} \text { of green tea extract (twice } \\
\text { daily) and topical application of a } \\
\text { green tea cream }(10 \%) \text {-two } \\
\text { times per day, for } 8 \text { weeks }\end{array}$ & $\begin{array}{l}\text { - No statistical changes of the skin of the patients from } \\
\text { both groups (dermatological examination) } \\
\text { - Skin biopsy revealed significant improvement in } \\
\text { elastic tissue content in the green tea treated group }\end{array}$ & [93] \\
\hline & & $\begin{array}{l}\text { Randomized single-blind, } \\
\text { placebo-controlled study } \\
20 \text { healthy Thai volunteers } \\
\text { (16 female and } 4 \text { male) aged } \\
\text { between } 20 \text { and } 35 \text { years old }\end{array}$ & $\begin{array}{l}\text { Cosmetics preparation, which } \\
\text { contained } 2 \%, 4.5 \% \text { and } 7 \% \text { of } \\
\text { green tea extract with } 100 \mathrm{mg} \% \text { of } \\
\text { polyphenols (the base consisted } \\
\text { of hydroxyethyl cellulose, } \\
\text { glycerin and panthenol). } \\
\text { Topical application for } 28 \text { days. }\end{array}$ & $\begin{array}{c}\text { - Significant anti-greasy and anti-sebum activity of a } \\
\text { green tea extract } \\
\text { - High efficiency in the improvement of oil face } \\
\text { condition } \\
\text { - The activity was highly correlated with the } \\
\text { concentration of green tea extract } \\
\text { - The effectiveness of a } 28 \text { days treatment was } \\
\text { significantly better than } 14 \text { days } \\
\text { - Patch testes revealed no irritation properties }\end{array}$ & [94] \\
\hline
\end{tabular}


Table 2. Cont

\begin{tabular}{|c|c|c|c|c|c|}
\hline \multirow{2}{*}{ Activity } & \multicolumn{2}{|c|}{ Experimental Model } & \multirow{2}{*}{ Type of Tea/Active Constituent } & \multirow{2}{*}{ Mechanism of Action/Effect } & \multirow{2}{*}{ Reference } \\
\hline & In vitro & In vivo/Ex vivo & & & \\
\hline & & $\begin{array}{c}\text { Single-blinded, placebo } \\
\text { controlled monocentric study } \\
22 \text { non-smoker, healthy men }\end{array}$ & $\begin{array}{l}\text { Cosmetic preparation containing } \\
\text { lotus and green tea extract. } \\
\text { Application on cheek at bedtime } \\
\quad \text { for } 60 \text { days. } \\
\text { Sebum production was evaluated } \\
\text { at baseline and after } 15,30,45 \\
\text { and } 60 \text { days. }\end{array}$ & $\begin{array}{c}\text { - Significant reduction of sebum production } \\
\text { - Higher efficacy in the group applying only green tea, } \\
\text { compared to a combination of green tea and lotus (not } \\
\text { statistically significant) } \\
\text { - The highest effectiveness was achieved after } 60 \text { days } \\
\text { of treatment }\end{array}$ & [95] \\
\hline & & $\begin{array}{l}\text { Clinical investigation-10 } \\
\text { healthy men aged } 24-40 \text { years }\end{array}$ & $\begin{array}{l}\text { Cosmetic formulation containing } \\
3 \% \text { of green tea extract applied to } \\
\text { the cheeks for } 8 \text { weeks. }\end{array}$ & $\begin{array}{c}\text { - Significant decrease in sebum production } \\
\text { - The highest efficiency was achieved after } 8 \text { weeks of } \\
\text { treatment ( } 60 \% \text { of sebum reduction) } \\
\text { - Significant improvement already after } 1 \text { week of } \\
\text { treatment (sebum production decreased by } 10 \%)\end{array}$ & [97] \\
\hline & $\begin{array}{l}\text { Hair follicles from } 14 \\
\text { biopsies, taken from the } \\
\text { vertex areas from male with } \\
\text { androgenic alopecia }\end{array}$ & & $\begin{array}{l}\text { Caffeine } \\
\text { External application of caffeine in } \\
\text { a concentration of } 0.001 \text { and } \\
0.005 \%\end{array}$ & $\begin{array}{l}\text { - Significant stimulation of hair follicle growth } \\
\text { - Reduction of a smooth muscle tension near the } \\
\text { hair follicle } \\
\text { - Significant increase of the nutrients delivery to a } \\
\text { hair papillae }\end{array}$ & [98] \\
\hline & & $\begin{array}{l}\text { Placebo controlled study } \\
\qquad 30 \text { mice }\end{array}$ & $\begin{array}{l}\text { Animals were fed with a diet } \\
\text { enriched with } 50 \% \text { fraction of } \\
\text { polyphenol extract from } \\
\text { dehydrated green tea in their } \\
\text { drinking water for six months }\end{array}$ & $\begin{array}{l}\text { - Significant improvement in hair growth ( } 33 \% \text { of } \\
\text { animals) in comparison to control group }\end{array}$ & [99] \\
\hline & $\begin{array}{l}\text { Cultured human dermal } \\
\text { papilla cells }\end{array}$ & $\begin{array}{l}\text { Hair follicles ex vivo culture } \\
\text { Three normal human } \\
\text { volunteers }\end{array}$ & $\begin{array}{c}\text { EGCG } \\
0.01,0.1 \text { or } 0.5 \mu \mathrm{M} \text { (in vitro) } \\
0.1,1 \text { or } 5 \mu \mathrm{M} \text { (ex vivo) } \\
10 \% \text { in ethanol or ethanol vehicle } \\
\text { (in vivo) }\end{array}$ & $\begin{array}{l}\text { - Stimulation of the culture cells growth } \\
\text { - Proliferative and anti-apoptotic effect towards dermal } \\
\text { papillae of human scalps } \\
\text { - Prolongation of anagen stage }\end{array}$ & [102] \\
\hline $\begin{array}{l}\text { Improvement of } \\
\text { skin } \\
\text { microcirculation }\end{array}$ & & $\begin{array}{l}\text { Double-blind, } \\
\text { placebo-controlled study } \\
60 \text { female volunteers }\end{array}$ & $\begin{array}{l}\text { Green tea beverage ( } 1402 \mathrm{mg} \text { of } \\
\text { catechins per day) for } 12 \text { weeks. }\end{array}$ & $\begin{array}{c}\text { - Significant improvement in blood flow ( } 40 \% \text { by week } \\
6 \text { and } 29 \% \text { by week } 12 \text { ) } \\
\text { - Significant improvement in oxygen delivery to the } \\
\text { skin (from } 30 \% \text { at the baseline up to } 38 \% \text { and } 40 \% \text { by } \\
\text { week } 6 \text { and } 12 \text {, respectively) } \\
\text { - Significant improvement of several skin parameters } \\
\text { (elasticity, roughness, scaling, density and } \\
\text { water homeostasis) }\end{array}$ & [5] \\
\hline
\end{tabular}


Table 2. Cont.

\begin{tabular}{|c|c|c|c|c|c|}
\hline \multirow{2}{*}{ Activity } & \multicolumn{2}{|c|}{ Experimental Model } & \multirow{2}{*}{ Type of Tea/Active Constituent } & \multirow{2}{*}{ Mechanism of Action/Effect } & \multirow{2}{*}{ Reference } \\
\hline & In vitro & In vivo/Ex vivo & & & \\
\hline & & $\begin{array}{l}\text { Randomized, double-blind, } \\
\text { single-dose study } \\
15 \text { female volunteers }\end{array}$ & $\begin{array}{l}\text { Green tea extract }(0.5,1.0 \text { and } \\
2.0 \mathrm{~g}) \text { administrated orally in a } \\
\text { form of capsule }\end{array}$ & $\begin{array}{l}\text { - Maximized blood flow } 30 \mathrm{~min} \text {. after ingestion } \\
\text { - Significant improvement of skin condition } \\
\text { - Increased blood flow and microcirculation in the } \\
\text { skin tissue }\end{array}$ & [5] \\
\hline & & $\begin{array}{l}\text { Clinical investigation in a } \\
\text { group of } 20 \text { volunteers (nine } \\
\text { men and } 11 \text { women) } \\
\text { with wounds }\end{array}$ & $\begin{array}{l}\text { Topical application of antiseptic } \\
\text { agent containing tee tree oil ( } 5 \% \\
\text { in a saline) }\end{array}$ & $\begin{array}{c}\text { - Significant increase (+19\%) of blood flow compared } \\
\text { to control } \\
\text { - Significant improvement of wound healing (in } \\
\text { comparison to ocetnidine and polyhexanide) } \\
\text { - Alterations in the hemoglobin oxygenation (not } \\
\text { significant) } \\
\text { - Significant improvement of skin perfusion } \\
\text { - Strong antibacterial activity }\end{array}$ & [103] \\
\hline & & $\begin{array}{l}\text { Clinical investigation in a } \\
\text { group of } 134 \text { women with } \\
\text { cellulite, aged between } \\
20-3 \text { years }\end{array}$ & $\begin{array}{l}\text { Commercially available cosmetic } \\
\text { (Elancyl }{ }^{\circledR} \text { Chrono-Active) } \\
\text { containing } 7 \% \text { of caffeine } \\
\text { Topical application for } 1 \text { month }\end{array}$ & $\begin{array}{c}\text { - Insignificant improvement of skin microcirculation } \\
\text { (functional capillary density, number of flowing } \\
\text { capillaries per unit area, diameter of the dermic papilla } \\
\text { and capillary diameter) } \\
\text { - Significant reduction of thigh and hip circumferences } \\
\text { in } 80 \% \text { and } 67 \% \text { of cases, respectively } \\
\text { - No influence of alcohol consumption, tobacco } \\
\text { smoking and level of physical activity on thigh and } \\
\text { hip circuit was revealed }\end{array}$ & [107] \\
\hline
\end{tabular}




\section{Skin Penetration of Tea Active Constituents}

The efficacy of cosmetic formulation is strictly correlated with the skin permeability of its active ingredients. One of the most important penetration-conditioning factors is the polarity of components. According to Yanagida and co-investigators [108] the partition coefficients (K(non-polar/polar)) of green tea polyphenols can be placed in the following order: ECG (6.25) > EGCG (2.94) > EC(2.38) > $\mathrm{C}(2.33)>\mathrm{EGC}(0.93)$. From all simple catechins present in tea extract EGC is considered as the most hydrophilic molecule, while ECG is characterized by the smallest polarity [108]. A study performed by Dal Belo and co-investigators [69] revealed that, after topical application of a green tea extract containing cream, EGCG was significantly retained within the skin, mostly in the stratum corneum, followed by the epidermis and dermis. This suggests a non-polar character of EGCG, as non-polar compounds tend to stay within the stratum corneum layer, and not penetrate into deeper parts of the skin, like the epidermis and dermis [109]. This is in agreement with a previous finding of Yanagida and co-workers, which also suggests a non-polar character of EGCG [108]. Zillich and co-investigators reported that both the size of the molecule as well as the hydrophobicity are the most crucial parameters regarding the ability of green tea catechins to penetrate the skin [6]. Definitely more experiments, especially in vivo and human studies, are needed to expand the knowledge on the bioavailability of tea polyphenols from cosmetic preparations.

Caffeine, a very important tea active constituent, is more often used as a hydrophilic model substance in skin penetration experiments. An in vitro study performed by Van de Sandt and co-workers [110] revealed that the maximal absorption rates of caffeine through the human skin were found to be $2.24 \pm 1.43 \mu \mathrm{g} / \mathrm{cm}^{2} / \mathrm{h}$. The authors have also proved that the maximal absorption of this alkaloid was reached $100 \mathrm{~min}$ after percutaneous application in the human skin [111]. Touitou and co-investigators studied caffeine skin delivery by carrier design [112]. Using quantitative skin autoradiography they have confirmed the highest concentration of caffeine ( $280 \mu \mathrm{g} / \mathrm{g}$ tissue) after $24 \mathrm{~h}$ in the epidermis, while the lowest amount of this alkaloid ( $50 \mathrm{~g} / \mathrm{g}$ tissue) was detected in the dermis. However, the caffeine's ability to penetrate from different cosmetic preparations through the skin barrier differs and is significantly correlated with the type of emulsion applied on the skin [72]. It occurs that its permeation mostly depends on the quantity of the formulation applied, rather than on the concentration of caffeine in the cosmetic formulation [113]. It was also proved that the composition of the cosmetic significantly affects caffeine absorption through the skin-water-in-oil nanoemulsion formulations were much more effective in comparison to aqueous solutions of caffeine, which was proved in Franz diffusion cells using rat skin as permeation membrane [114]. An effective way to transfer caffeine through the skin barrier was based on the application of microspheres in aqueous suspension (diameter of the microspheres: $2.8 \mu \mathrm{m}$, caffeine loading: $2.3 \mathrm{mg} / \mathrm{g}$ of particles). Such a formulation improved caffeine transfer across the skin, as microspheres easily penetrated the skin barrier and gathered in the receptor compartment, providing continuous alkaloid release [71,115]. Taking all into consideration it should be remembered that not only the quality of the tea extract or the concentration of caffeine, but first of all the composition of the cosmetic formulation is significant for the effectiveness of topical applications containing this alkaloid.

\section{Skincare Products Containing Tea Extracts}

Tea extracts are important components of many cosmetics, including creams, moisturizing lotions, tonics, shower gels, hair products as well as cosmetic facial masks. That frequent use of Camellia sinensis extracts is due to its multidirectional effect. From all types of tea extracts, those obtained from green tea are the most widely used. These are proposed not only for young and problematic skin types, as they inhibit excessive sebum production, but can also be used by people with sensitive and allergic skin $[11,38]$. However, on the market also cosmetic products containing black and white tea can be found and their popularity is increasing. Due to a many producers and cosmetic forms a large number of different products can be found and their exact number is hard to estimate, also because almost every year new products appear on the market. Table 3 presents an example of 
30 different cosmetics containing green, black and white extracts, including a type of a cosmetic form and manufacturer's recommendations.

Table 3. Selected examples of cosmetic products containing tea.

\begin{tabular}{|c|c|c|c|}
\hline Tea Extract & Cosmetic Product & $\begin{array}{c}\text { Cosmetic's Effects (Manufacturer's } \\
\text { Declaration) }\end{array}$ & Production Area \\
\hline Green tea & Peeling mask & $\begin{array}{l}\text { - Improved skin regeneration based on the } \\
\text { antioxidant, anti-inflammatory and toning } \\
\text { properties of green tea }\end{array}$ & Poland \\
\hline Green tea & Face mask & $\begin{array}{l}\text { - Strong soothing, anti-inflammatory and } \\
\text { regenerative properties } \\
\text { - antioxidant activity } \\
\text { - Protection against harmful environmental } \\
\text { influences }\end{array}$ & Poland \\
\hline Green tea & Face mask & $\begin{array}{l}\text { - Eliminated excess sebum } \\
\text { - Proper skin hydration }\end{array}$ & USA \\
\hline Green tea & Shampoo & $\begin{array}{l}\text { - Hair care for normal and slightly damaged hair } \\
\text { - Antioxidant properties } \\
\text { - Soothing action towards sensitive scalp (slightly } \\
\text { moisturized and refreshed) }\end{array}$ & Poland \\
\hline Green tea (Fuji) & Shampoo & $\begin{array}{c}\text { - Hair care for normal hair } \\
\text { - Refreshed and purified hair and scalp }\end{array}$ & UK \\
\hline Green tea (Matcha) & Shampoo & $\begin{array}{l}\text { - Reduction of dandruff and greasy hair } \\
\text { - Clarified and toned scalp } \\
\text { - Intensive shine }\end{array}$ & UK \\
\hline Green tea & Shampoo & $\begin{array}{l}\text { - Antioxidant in hair care (protection of hair } \\
\text { against free radicals) } \\
\text { - Hydrated and moisturized scalp }\end{array}$ & Malaysia \\
\hline Green tea & Hair conditioner & $\begin{array}{c}\text { - Hair care for all hair types } \\
\text { - Protection against moisture loss } \\
\text { - Strong antioxidant and hair growth stimulant } \\
\text { properties } \\
\text { - Smooth and soft hair }\end{array}$ & UK \\
\hline Green tea & Hair conditioner & $\begin{array}{c}\text { - Strengthens hair } \\
\text { - Antioxidant properties towards hair }\end{array}$ & Japan \\
\hline Green tea & Hand and Body Lotion & $\begin{array}{l}\text { - Nourishing cream for feet, hands and body } \\
\text { - Makes the skin smooth and hydrated }\end{array}$ & USA \\
\hline Green tea & Body lotion & $\begin{array}{l}\text { - A fresh fragrance } \\
\text { - Refreshing body and mind } \\
\text { - Improved mood }\end{array}$ & USA \\
\hline Green tea & Balancing lotion & $\begin{array}{l}\text { - Superior hydration and nourishment of the skin } \\
\text { - Softened and smoothed, cleansed skin leaving }\end{array}$ & USA \\
\hline Green tea & Refreshing body lotion & $\begin{array}{c}\text { - Hydrated skin } \\
\text { - Skin fragrance for a long time }\end{array}$ & USA \\
\hline Green tea & Body cream & $\begin{array}{l}\text { - Nourished and moisturized skin } \\
\text { - Smoothed skin } \\
\text { - Soft and flexible skin } \\
\text { - Skin care for all skin types }\end{array}$ & USA \\
\hline Green tea (Fuji) & Hand cream & $\begin{array}{l}\text { - Nourished hands' skin } \\
\text { - Softer and smoother hands }\end{array}$ & UK \\
\hline Green tea (Matcha) & Hand cream & $\begin{array}{l}\text { - Skin care for all skin types } \\
\text { - Nourished and moisturized skin of the hands }\end{array}$ & UK \\
\hline Green tea & Eye cream & $\begin{array}{l}\text { - Removed six types of wrinkles under the eyes } \\
\text { - Improved production of hyaluronic acid by } \\
\text { epidermal cells } \\
\text { - Restored moisture in the skin to fill fine lines in } \\
\text { dry skin }\end{array}$ & Japan \\
\hline Black tea & Face mask & $\begin{array}{l}\text { - Nourished and smoothed skin } \\
\text { - Antioxidant properties towards the skin }\end{array}$ & USA \\
\hline
\end{tabular}


Table 3. Cont.

\begin{tabular}{|c|c|c|c|}
\hline Tea Extract & Cosmetic Product & $\begin{array}{l}\text { Cosmetic's Effects (Manufacturer's } \\
\text { Declaration) }\end{array}$ & Production Area \\
\hline Black tea & Instant perfecting mask & $\begin{array}{c}\text { Black tea complex: } \\
\text { - Protection against harmful effects of the } \\
\text { environment } \\
\text { - Reduction of the skin roughness, improved } \\
\text { glow and elasticity } \\
\text { - Softened, smoothed and soothed the skin }\end{array}$ & EU \\
\hline $\begin{array}{l}\text { Black tea (Darjeeling } \\
\text { tea) }\end{array}$ & Antiwrinkle cream & $\begin{array}{l}\text { - Protection against any harmful environmental } \\
\text { factors } \\
\text { - Moisturized and revitalized skin }\end{array}$ & South Korea \\
\hline Black tea & Shampoo & $\begin{array}{l}\text { - Everyday shampoo for all types of hair } \\
\text { - Removed build-up and excess oils }\end{array}$ & UK \\
\hline Black tea & Lotion & $\begin{array}{c}\text { - Hydration and the look of firm, radiant skin } \\
\text { - Provided SPF } 20 \text { UVA/UVB sun protection } \\
\text { - Protection against UV and free radicals-induced } \\
\text { damage } \\
\text { Recommended for: } \\
\text { - Dryness } \\
\text { - Dullness/uneven texture } \\
\text { - Loss of firmness/elasticity }\end{array}$ & EU \\
\hline Black tea & Body cream & $\begin{array}{l}\text { - Antioxidant benefits towards the skin } \\
\text { - Smoothed and moisturized the skin }\end{array}$ & USA \\
\hline Black tea & Firming corset cream & $\begin{array}{l}\text { Black tea complex: } \\
\text { - Firms and redefines the contours } \\
\text { - Prevents loss of elasticity and smoothness } \\
\text { - Makes the skin look healthier and younger } \\
\text { - Protects the skin against free radicals }\end{array}$ & EU \\
\hline Black tea & Eye concentrate & $\begin{array}{l}\text { Black tea complex: } \\
\text { - Firmed and redefined eye contour } \\
\text { - Increased elasticity and smoothness } \\
\text { - Healthier and more youthful appearance }\end{array}$ & EU \\
\hline Black tea & Hand cream & $\begin{array}{l}\text { - Hand skin care for all skin types } \\
\text { - Regenerated and smoothed the skin }\end{array}$ & UK \\
\hline White tea & Body cream & - Softened and hydrated skin & USA \\
\hline White tea & Shower gel & - Refreshed and softened fragrant skin & USA \\
\hline White tea & Toilet water & - Fragrant skin & USA \\
\hline White tea & Hand cream & - Alleviated rough patches and calluses & USA \\
\hline
\end{tabular}

According to Możdżeń and co-workers, who analyzed the plant species, which are used to produce cosmetic masks offered on the Polish market, Camellia sinensis is the most commonly used, followed by Matricaria chamomilla L. and Vitis vinifera L. [116].

After applying cosmetics containing tea extract, the skin appears more tense and refreshed, which is the result of astringent activity of polyphenols and tannins and their interaction with keratin present in the stratum corneum. This process also leads to a reduction in skin redness, irritation and reduction of swelling. The facial masks, containing mainly green tea extracts, have a disinfecting, antioxidant and toning effect. They also soothe inflammation, accelerate the healing of wounds and skin eruptions, and also close skin pores by which they reduce their visibility [116].

Tea infusions are also used as compresses, which are applied after insect bites [76] or to soothe the itching and burning around the eyes.

The latter effect results from the vasoconstriction induced by the metabolites of tea plant and is shown up as a noticeable reduction of swelling around the eyes, which is often observed during inflammation [11,76].

\section{Conclusions and Perspectives}

Plentiful of biological effects of Camellia sinensis presented in this review shed light on the application of its extracts in cosmetics apart from its better known usage in pharmaceutics. Tea plant 
leaves are the most rich sources of catechins among plants, but also deliver caffeine-a purine alkaloid of high cosmetic significance. Together with the development of the analytical instrumentation and biological activity evaluation methodology, further precious properties of this plant were revealed towards skin. The administration of tea plant in cosmetics seems to be interesting and precious, due to the fact that it does not have any confirmed allergenic or irritating effects after topical administration. Low toxicity of single metabolites of its extracts, often appearing as synergistic actions with other antioxidants commonly added to different types of products and additional preserving properties towards final cosmetics formulations encourages the use of tea plant metabolites in various applications.

Among the benefits of tea plant and its extracts, its value in the anti-ageing treatment, skin and hair care and slimming properties should be underlined. Its constituents are also effective in the skin microcirculation enhancement and photoprotection against harmful effects of UV irradiation.

Therefore, it is of the highest importance to collect funds on the Camellia sinensis fermentation type-bioactivity studies to reveal some more relations between the type $\mathrm{f}$ manufacturing process and the obtained biological effects. Still the largest quantity of scientific results has been obtained for the green tea extracts. The other types of leaves' fermentation due to their different composition needs further investigations, as they are also responsible for noticeable effects towards skin. On the other hand, further trials on human skin or humans of all types of tea are necessary to confirm its therapeutic benefits already revealed in in vitro models.

Certainly, this still insufficiently studied plant in terms of its cosmetic applications will draw attention of researchers working in this sector in the nearest future.

Author Contributions: W.K. and W.K.-K. have designed the manuscript, W.K., W.K.-K., J.Z., Z.M. prepared the original draft of the manuscript; W.K. has reviewed the manuscript.

Funding: This research was funded by the Medical University of Lublin within the statutory funds (DS No 07) of the Chair and Department of Food and Nutrition.

Conflicts of Interest: The authors declare no conflict of interest.

\section{Abbreviations}

C

cAMP adenosine cyclic $3^{\prime} 5^{\prime}$-monophosphate

CD capillary diameter

CD1a+ epidermal Langerhans cells

COX-1 cyclooxygenase 1

DHT dihydrotestosterone

DPD dermic papilla diameter

EC (-)-epicatechin

ECG (-)-epicatechin gallate

EGC (-)-epigallocatechin

EGCG (-)-epigallocatechin gallate

FCD functional capillary density

GA gallic acid

GC (-)-gallocatechin

GCG (-)-gallocatechin gallate

HSL hormonesensitive lipase

IL-10 interleukin 10

$\mathrm{NaCl}$ natrium chloride

NHEK normal human epidermal keratinocytes

RNS

ROS

SOD

TB

TF

TF1

TF2A

TF2B

TF3 reactive nitrogen species

reactive oxygen species

super oxide dismutase

theobrownins

theaflavins

theaflavin

theaflavin 3-gallate

theaflavin $3^{\prime}$-gallate

3-3'-theaflavin digalusate 
TR

TXAS

UV

thearubigins

UVR

thromboxane synthase

ultraviolet

ultraviolet radiation

\section{References}

1. Dylewska-Grzelakowska, J. Kosmetyka Stosowana, 9th ed.; WSziP: Warsaw, Poland, 2010; pp. 71-74.

2. Arct, J.; Pytkowska, K. Flavonoids as components of biologically active cosmeceuticals. Clin. Dermatol. 2008, 26, 347-357. [CrossRef]

3. Arct, J.; Bielenda, B.; Oborska, A.; Pytkowska, K. The tea and its cosmetic application. J. Appl Cosmetol. 2003, 21, 117-127.

4. Gianeti, M.D.; Mercurio, D.G.; Campos, P.M. The use of green tea extract in cosmetic formulations: Not only an antioxidant active ingredient. Dermatologic Therapy 2013, 26, 267-271. [CrossRef]

5. Heinrich, U.; Moore, C.E.; De Spirt, S.; Tronnier, H.; Stahl, W. Green tea polyphenols provide photoprotection, increase microcirculation, and modulate skin properties of women. J. Nutr. 2011, 141, 1202-1208. [CrossRef]

6. Saric, S.; Manisha, N.; Sivamani, R.K. Green tea and other tea polyphenols: Effects on sebum production and acne vulgaris. Antioxidants 2017, 6, 2. [CrossRef]

7. Herman, A.; Herman, A.P. Caffeine's mechanisms of action and its cosmetic use. Skin Pharmacol. Physiol. 2013, 26, 8-14. [CrossRef]

8. Sumpio, B.E.; Cordova, A.C.; Berke-Schlessel, D.W.; Qin, F.; Chen, Q.H. Green tea, the "Asian Paradox", and cardiovascular disease. J. Am. Coll. Surg. 2006, 202, 813-820. [CrossRef]

9. Wang, H.; Provan, G.J.; Helliwell, K. Tea flavonoids: Their functions, utilization and analysis. Trends Food. Sci. Technol. 2000, 11, 152-160. [CrossRef]

10. Pauli, E.D.; Scarmino, I.S.; Tauler, R. Analytical investigation of secondary metabolites extracted from Camellia sinensis L. leaves using a HPLC-DAD-ESI/MS data fusion strategy and chemometric methods. J. Chemom. 2016, 30, 75-85. [CrossRef]

11. Lamer-Zarawska, E.; Kowal-Gierczak, B.; Niedworok, J. Fitoterapia i Leki Roślinne, 1st ed.; Wydawnictwo Lekarskie PZWL: Warsaw, Poland, 2012; pp. 136-140.

12. Yao, L.H.; Jiang, Y.M.; Caffin, N.; D'Arcy, B.; Datta, N.; Liu, X.; Singanusong, R.; Xu, Y. Phenolic compounds in tea from Australian supermarkets. Food Chem. 2006, 96, 614-620. [CrossRef]

13. Zuo, Y.; Chen, H.; Deng, Y. Simultaneous determination of catechins, caffeine and gallic acids in green, Oolong, black and pu-erh teas using HPLC with a photodiode array detector. Talanta 2002, 57, 307-316. [CrossRef]

14. Crespy, V.; Williamson, G. A review of the health effects of green tea catechins in in vitro animal models. J. Nutr. 2004, 134, 3431S-3440S. [CrossRef]

15. Thanaraj, S.N.; Seshardi, R. Influence of polyphenol oxidase activity and polyphenol content of tea shoot on quality of black tea. J. Sci. Food Agric. 1990, 51, 57-69. [CrossRef]

16. Balentine, D.A.; Wiseman, S.A.; Bouwens, L.C. The chemistry of tea flavonoids. Crit. Rev. Food Sci. Nutr. 1997, 37, 693-704. [CrossRef]

17. Sajilata, M.G.; Bajaj, P.R.; Singhal, R.S. Tea polyphenols as nutraceuticals. Compr. Rev. Food Sci. Food Saf. 2008, 7, 229-254. [CrossRef]

18. Tsai, P.H.; Kan, N.B.; Ho, S.C.; Liu, C.C.; Lin, C.C. Effects of oolong tea supplementationon lipid peroxidation of athletes at rest and post-exhaustive exercise. J. Food Sci. 2005, 70, 581-585. [CrossRef]

19. Yang, C.H.S.; Wang, X.; Lu, G.L.; Picinich, S.C. Cancer prevention by tea: Animal studies, molecular mechanisms and human relevance. Nat. Rev. Cancer 2009, 9, 429-439. [CrossRef]

20. Hua-Feng, H. Research progress on theaflavins: Efficacy, formation, and preparation. Food Nutr. Res. 2017, 61, 1344521. [CrossRef]

21. Koch, W.; Kukula-Koch, W.; Komsta, Ł. Black Tea Samples Origin Discrimination Using Analytical Investigation of Secondary Metabolites, Antiradical Scavenging Activity and Chemometric Approach. Molecules 2018, 23, 513. [CrossRef]

22. Record, I.R.; Lane, J.M. Simulated intestinal digestion of green and black teas. Food Chem. 2001, 73, 481-486. [CrossRef] 
23. Yamamoto, T.; Juneja, L.R.; Chu, D.C.; Kim, M. Chemistry and Applications of Green Tea; CRC Press: Boca Raton, NY, USA, 1997; pp. 13-16, 45-60.

24. Cabrera, C.; Artacho, R.; Gimenez, R. Beneficial effects of green tea-A review. J. Am. Coll. Nutr. 2006, 25, 79-99. [CrossRef] [PubMed]

25. Zhu, M.; Xiao, P.G. Quantitative analysis of active constituents of green tea. Phytother. Res. 1991, 5, 239.

26. Juneja, L.R.; Chu, D.-C.; Okubo, T.; Nagato, Y.; Yokogoshi, H. L-theanine-a unique amino acid of green tea and its relaxation effect in humans. Trends Food Sci. Technol. 1999, 10, 199-204. [CrossRef]

27. Hara, Y.; Luo, S.J.; Wickremashinghe, R.L.; Yamanishi, T.V.I. Biochemistry of processing black tea. Food Rev. Int. 1995, 11, 457-471.

28. Hui, Y.H. Encyclopedia of Food Science and Technology; Wiley-Interscience Publication. John Wiley and Sons: New York, NY, USA, 1992; pp. 3-4.

29. Kök, E.; Taşcioğlu, S. Temperature Dependence of Copper and Chromium Transfer into Various Black and Green Tea Infusions. J. Sci. Food Agric. 1998, 76, 200-298. [CrossRef]

30. Fernảndez-Cảceres, P.L.; Martin, M.J.; Pablos, F.; Gonzảlez, A.G. Differentiation of tea (Camellia sinensis) varieties and their geographical origin according to their metal content. J. Agric. Food Chem. 2001, 49, 4775-4779. [CrossRef]

31. Gramza, a.; Korczak, J.; Amarowicz, R. Tea polyphenols-their antioxidant properties and biological activity-A review. Pol. J. Food Nutr. Sci. 2005, 14, 219-235.

32. Kanitakis, J. Anatomy, histology and immunohistochemistry of normal human skin. Eur. J. Dermatol. 2002, $12,390-401$.

33. James, W.D.; Berger, T.G.; Elston, D.M. Andrews' Dis-eases of the Skin: Clinical Dermatology, 10th ed.; Elsevier: Saunders, PA, USA, 2006.

34. Murphy, G.F. Histology of the Skin. In Lever's Histopathology of the Skin, 8th ed.; Elder, D., Elenitsas, R., Jaworsky, C., Johnson, B., Jr., Eds.; Lippincott Williams \& Wilkins: Philadelphia, PA, USA, 1997; pp. 5-45.

35. Chu, D.H. Overview of Biology, Development, and Structure of Skin. In Fitzpatrick's Dermatology in General Medicine, 7th ed; Wolff, K., Goldsmith, L.A., Katz, S.I., Gilchrest, B.A., Paller, A.S., Leffell, D.J., Eds.; McGraw-Hill: New York, NY, USA, pp. 57-73.

36. Deana, R.; Turetta, L.; Donella-Deana, A.; Donà, M.; Brunati, A.M.; De Michiel, L.; Garbisa, S. Green tea epigallocatechin-3-gallate inhibits platelet signalling pathways triggered by both proteolytic and non-proteolytic agonists. Thromb. Haemost. 2003, 89, 866-874. [CrossRef]

37. Lee, D.-H.; Kim, Y.-J.; Kim, H.-H.; Cho, H.-J.; Ryu, J.-H.; Rhee, M.-H.; Park, H.-J. Inhibitory effects of epigallocatechin-3-gallate on microsomal cyclooxygenase-1 activity in platelets. Biomol. Ther. (Seoul) 2013, 21, 54-59. [CrossRef]

38. Gabor, M.B. Pharmacologic effects of flavonoids on blood vessels. Angiol 1972, 9, 355-374. [CrossRef] [PubMed]

39. Koch, W. Dietary polyphenols-important non-nutrients in the prevention of chronic noncommunicable diseases. A systematic review. Nutrients 2019, 11, 1039. [CrossRef] [PubMed]

40. Mishra, A.; Kumar, S.; Pandey, A.K. Scientific validation of the medicinal efficacy of Tinospora cordifolia. Sci. World J. 2013, 292934. [CrossRef]

41. Kukula-Koch, W.; Aligiannis, N.; Halabalaki, M.; Skaltsounis, A.L.; Glowniak, K.; Kalpoutzakis, E. Influence of extraction procedures on phenolic content and antioxidant activity of Cretan barberry herb. Food Chem. 2013, 138, 406-413. [CrossRef]

42. Velioglu, Y.S.; Mazza, G.; Gao, L.; Oomah, B.D. Antioxidant activity and total phenolics in selected fruits, vegetables and grain products. J. Agric. Food Sci. 1998, 46, 4113-4117. [CrossRef]

43. Kumar, S.; Mishra, A. Chemistry and biological activities of flavonoids: An overview. Sci. World J. 2013, 162750. [CrossRef]

44. Almajano, P.; Carbo, R.; Lopez Jimenez, J.A.; Gordon, M.H. Antioxidant and antimicrobial activities of tea infusions. Food Chem. 2008, 108, 55-63. [CrossRef]

45. Yang, C.-S.; Lambert, J.D.; Sang, S. Antioxidative and anti-carcinogenic activities of tea polyphenols. Arch. Toxicol. 2009, 83, 11-21. [CrossRef]

46. Sung, H.; Nah, J.; Chun, S.; Park, H.; Yang, S.E.; Min, W.K. In vivo antioxidant effect of green tea. Eur. J. Clin. Nutr. 2000, 54, 527-529. [CrossRef] [PubMed] 
47. Arent, S.M.; Senso, M.; Golem, D.L. The effects of theaflavin-enriched black tea extract on muscle soreness, oxidative stress, inflammation, and endocrine responses to acute anaerobic interval training: A randomized, double-blind, crossover study. J. Int. Soc. Sport. Nutr. 2010, 7, 11. [CrossRef]

48. Vinson, J.A.; Teufel, K.; Wu, N. Green and black teas inhibit atherosclerosis by lipid, antioxidant, and fibrinolytic mechanisms. J. Agric. Food Chem. 2004, 52, 3661-3665. [CrossRef] [PubMed]

49. Frei, B.; Higdon, J.V. Antioxidant activity of tea polyphenols in vivo: Evidence from animal studies. J. Nutr. 2003, 133, 3275-3284. [CrossRef] [PubMed]

50. Koch, W.; Kukula-Koch, W.; Komsta, Ł.; Marzec, Z.; Szwerc, W.; Głowniak, K. Green tea quality evaluation based on its catechins and metals composition in combination with chemometric analysis. Molecules 2018, 23, 1689. [CrossRef]

51. Bekbolatova, E.; Kukula-Koch, W.; Baj, T.; Stasiak, N.; Ibadulllayeva, G.; Koch, W.; Głowniak, K.; Tulemissov, S.; Sakipova, Z.; Boylan, F. Phenolic composition and antioxidant potential of different organs of Kazakh Crataegus almaatensis Pojark: A comparison with the European Crataegus oxyacantha L. flowers. Open Chem. 2018, 16, 415-426. [CrossRef]

52. Oniszczuk, T.; Widelska, G.; Oniszczuk, A.; Kasprzak, K.; Wójtowicz, A.; Olech, M.; Nowak, R.; Wojtunik-Kulesza, K.; Jóźwiak, G.; Waksmundzka-Hajnos, M. Influence of Production Parameters on the Content of Polyphenolic Compounds in Extruded Porridge Enriched with Chokeberry Fruit (Aronia melanocarpa (Michx.) Elliott). Open Chem. 2019, 17, 166-176. [CrossRef]

53. Stój, A.; Szwajgier, D.; Baranowska-Wójcik, E.; Domagała, D. Gentisic Acid, Salicylic Acid, Total Phenolic Content and Cholinesterase Inhibitory Activities of Red Wines Made from Various Grape Varieties. S. Afr. J. Enol. Vitic. 2019, 40. [CrossRef]

54. Hęś, M.; Dziedzic, K.; Górecka, D.; Jędrusek-Golińska, A.; Gujska, E. Aloe vera (L.) Webb.: Natural Sources of Antioxidants-A Review. Plant Foods Hum. Nutr. 2019, 74, 255-265. [CrossRef]

55. Kukula-Koch, W.; Kędzierski, B.; Głowniak, K. Influence of extrahent on antioxidant capacity of Aesculus hippocastanum seeds. Nat. Prod. Res. 2014. [CrossRef]

56. Koch, W.; Baj, T.; Kukula-Koch, W.; Marzec, Z. Dietary intake of specific phenolic compounds and their effect on the antioxidant activity of daily food rations. Open Chem. 2015, 13, 869-876. [CrossRef]

57. Zhang, S.; Duan, E. Fighting against skin aging the way from bench to bedside. Cell Transplant. 2018, 27, 729-738. [CrossRef]

58. Draelos, Z.D. Therapeutic moisturizers. Dermatol. Clin. 2000, 18, 597-607. [CrossRef]

59. Lipozencic', J.; Pastar, Z.; Marinovic'-Kulisic', S. Moisturizers. Acta Dermatovenerol. Croat. 2006, 14, $104-108$.

60. Halliday, G.M. Inflammation, gene mutation and photoimmunosuppression in response to UVR-induced oxidative damage contributes to photocarcinogenesis. Mutat. Res. 2005, 571, 107-120. [CrossRef] [PubMed]

61. Meunier, L.N.; Raison-Peyron, N.; Meynadier, J. UV-induced immunosuppression and skin cancers. Rev. Med. Interne. 1998, 19, 247-254. [CrossRef]

62. Camouse, M.M.; Domingo, D.S.; Swain, F.R.; Conrad, E.P.; Matsui, M.S.; Maes, D.; Declercq, L.; Cooper, K.D.; Stevens, S.R.; Baron, E.D. Topical application of green and white tea extracts provides protection from solar-simulated ultraviolet light in human skin. Exp. Dermatol. 2009, 18, 522-526. [CrossRef]

63. Morley, N.; Clifford, T.; Salter, L.; Campbell, S.; Gould, D.; Curnow, A. The green tea polyphenol (-)-epigallocatechin gallate and green tea can protect human cellular DNA from ultraviolet and visible radiation-induced damage. Photodermatol. Photoimmunol. Photomed. 2005, 21, 15-22. [CrossRef]

64. Mishra, A.K.; Mishra, A.; Chattopadadhyay, P. Herbal cosmeceuticals from ultraviolet B radiation: A review. Trop. J. Pharm. Res. 2011, 10, 351-359. [CrossRef]

65. Yarnell, E.; Abascal, K. Herbal sunscreens and ultraviolet protectants. Altern. Compl. Ther. 2012, 18, 141-144. [CrossRef]

66. Ferrazzano, G.F.; Amato, I.; Ingenito, A.; De Natale, A.; Pollio, A. Anti-cariogenic effects of polyphenols from plant stimulant beverages (cocoa, coffee, tea). Fitoterapia 2009, 80, 255-262. [CrossRef]

67. Wang, S.Q.; Balagula, Y.; Osterwalder, U. Photoprotection: A review of the current and future technologies. Dermatol. Th. 2010, 23, 31-47. [CrossRef]

68. Mnich, C.D.; Hoek, K.S.; Virkki, L.V.; Farkas, A.; Dudli, C.; Laine, E.; Urosevic, M.; Dummer, R. Green tea extract reduces induction of $\mathrm{p} 53$ and apoptosis in UVB-irradiated human skin independent of transcriptional controls. Exp. Dermatol. 2009, 18, 69-77. [CrossRef] [PubMed] 
69. Dal Belo, S.E.; Gaspar, L.R.; Maia Campos, P.M. Photoprotective effects of topical formulations containing a combination of Ginkgo biloba and green tea extracts. Phytother. Res. 2011, 25, 1854-1860. [CrossRef] [PubMed]

70. Katiyar, S.K. Skin photoprotection by green tea: Antioxidant and immunomodulatory effects. Curr. Drug Targets Immun. Endocr. Metabol. Disord. 2003, 3, 234-242. [CrossRef] [PubMed]

71. Rawlings, A.V. Cellulite and its treatment. Int. J. Cosmet. Sci. 2006, 28, 175-190. [CrossRef]

72. Cawthorn, W.P.; Sethi, J.K. TNF- $\alpha$ and adipocyte biology. FEBS Lett. 2008, 582, 117-131. [CrossRef]

73. Conti, M. Phosphodiesterases and cyclic nucleotide signaling in endocrine cells. Mol. Endocrinol. 2000, 14, 1317-1327. [CrossRef]

74. Biernikiewicz, M. Spa\&Wellness. In Inspiration, 1st ed.; SpaPartners: Wrocław, Poland, 2010; pp. 21-35.

75. Romer, M. Aromaterapia. Leksykon Roślin Leczniczych (Aromatherapy. Lexicon of Medicinal Plants), 1st ed.; MedPharm: Wrocław, Poland, 2007; pp. 39-41.

76. Majewska, K.; Older, D.; Pawełczyk, A.; Zaprutko, T.; Żwawiak, J.; Zaprutko, L. Aktywne kosmetyki wśród produktów spożywczych. Homines Hominibus 2010, 6, 65-96.

77. Panchal, S.K.; Poudyal, H.; Waanders, J.; Brown, L. Coffee extract attenuates changes in cardiovascular and hepatic structure and function without decreasing obesity in high-carbohydrate, high-fat diet-fed male rats. J. Nutr. 2012, 142, 690-697. [CrossRef]

78. Vogelgesang, B.; Bonnet, I.; Godard, N.; Sohm, B.; Perrier, E. In vitro and in vivo efficacy of sulfo-carrabiose, a sugar-based cosmetic ingredient with anti-cellulite properties. Int. J. Cosmet. Sci. 2011, 33, 120-125. [CrossRef]

79. Pires-de-Campos, M.S.; Leonardi, G.R.; Chorilli, M.; Spadari-Bratfisch, R.C.; Polacow, M.L.; Grassi-Kassisse, D.M. The effect of topical caffeine on the morphology of swine hypodermis as measured by ultrasound. J. Cosmet. Dermatol. 2008, 7, 232-237. [CrossRef]

80. Velasco, M.V.; Tano, C.T.; Machado-Santelli, G.M.; Consiglieri, V.O.; Kaneko, T.M.; Baby, A.R. Effects of caffeine and siloxanetriol alginate caffeine, as anticellulite agents, on fatty tissue: Histological evaluation. J. Cosmet. Dermatol. 2008, 7, 23-29. [CrossRef] [PubMed]

81. Byun, S.-Y.; Kwon, S.-H.; Heo, S.-H.; Shim, J.-S.; Du, M.-H.; Na, J.-I. Efficacy of Slimming Cream containing $3.5 \%$ water-soluble caffeine and xanthenes for the treatment of cellulite: Clinical study and literature review. Ann. Dermatol. 2015, 27, 243-249. [CrossRef] [PubMed]

82. Huang, J.; Wang, Y.; Xie, Z.; Zhou, Y.; Zhang, Y.; Wan, X. The anti-obesity effects of green tea in human intervention and basic molecular studies. Eur. J. Clin. Nutr. 2014, 68, 1075-1087. [CrossRef]

83. Moon, H.S.; Lee, H.G.; Choi, Y.J.; Kim, T.G.; Cho, C.S. Proposed mechanisms of (-)-epigallocatechin-3-gallate for anti-obesity. Chem. Biol. Interact. 2007, 167, 85-98. [CrossRef]

84. Nagao, T.; Hase, T.; Tokimitsu, I. A green tea extract high in catechins reduces body fat and cardiovascular risks in humans. Obesity 2007, 15, 1473-1483. [CrossRef]

85. Bose, M.; Lambert, J.D.; Ju, J.; Reuhl, K.R.; Shapses, S.A.; Yang, C.S. The major green tea polyphenol, (-)-epigallocatechin-3 gallate, inhibits obesity, metabolic syndrome, and fatty liver disease in high-fat-fed mice. J. Nutr. 2008, 138, 1677-1683. [CrossRef]

86. Cialdella-Kam, L.; Ghosh, S.; Meaney, M.P.; Knab, A.M.; Shanely, R.A.; Nieman, D.C. Quercetin and green tea extract supplementation downregulated genes related to tissue inflammatory responses to a 12-week high fat-diet in mice. Nutrients 2017, 9, 773. [CrossRef]

87. Rao, J.; Paabo, K.E.; Goldman, M.P. A double-blinded randomized trial testing the tolerability and efficacy of a novel topical agent with and without occlusion for the treatment of cellulite: A study and review of the literature. J. Drugs Dermatol. 2004, 3, 417-425.

88. Chen, N.; Bezzina, R.; Hinch, E.; Lewandowski, P.A.; Cameron-Smith, D.; Mathai, M.L.; Jois, M.; Sinclair, A.J.; Begg, D.P.; Wark, J.D.; et al. Green tea, black tea, and epigallocatechin modify body composition, improve glucose tolerance, and differentially alter metabolic gene expression in rats fed a high-fat diet. Nutr. Res. 2009, 29, 784-793. [CrossRef]

89. Wang, S.; Moustaid-Moussa, N.; Chen, L.; Mo, H.; Shastri, A.; Su, R.; Bapat, P.; Kwun, I.; Shen, C.L. Novel insights of dietary polyphenols and obesity. J. Nutr. Biochem. 2014, 25, 1-18. [CrossRef]

90. Savikin, K.; Menković, N.; Zdunić, G.; Pljevljakušić, D.; Spasić, S.; Kardum, N.; Konić-Ristić, A. Dietary supplementation with polyphenol-rich chokeberry juice improves skin morphology in cellulite. J. Med. Food 2014, 17, 582-587. [CrossRef] [PubMed] 
91. Farris, P. Idebenone, green tea, and coffeeberry extract: New and innovative antioxidants. Dermatol. Ther. 2007, 20, 322-329. [CrossRef] [PubMed]

92. Syed, T.A.; Wong, W.H.; Ahmad, S.A.; Aly, R. Phase II, clinical evaluation of $2 \%$ polyphenone (green tea extract) in a hydrophilic gel to assess improvement in damaged and premature aged facial skin. A placebo-controlled, double blind study. J. Am. Acad. Dermatol. 2004, 50, 25. [CrossRef]

93. Chiu, A.E.; Chan, J.L.; Kern, D.G.; Kohler, S.; Rehmus, W.E.; Kimball, A.B. Double-blinded, placebo-controlled trial of green tea extracts in the clinical and histologic appearance of photoaging skin. Dermatol. Surg. 2005, 31, 855-860. [CrossRef]

94. Meethama, P.; Kanlayavattanakula, M.; Louritha, N. Development and clinical efficacy evaluation of anti-greasy green tea tonner on facial skin. Rev. Bras. Farmacogn. 2018, 28, 214-217. [CrossRef]

95. Mahmood, T.; Akhtar, N.; Khan, B.A.; Khan, H.M.; Saeed, T. Outcomes of $3 \%$ green tea emulsion on skin sebum production in male volunteers. Bosn. J. Basic Med. Sci. 2010, 10, 260-264. [CrossRef]

96. Mahmood, T.; Akhtar, N.; Moldovan, C. A comparison of the effects of topical green tea and lotus on facial sebum control in healthy humans. Hippokratia 2013, 17, 64-67.

97. Lourith, N.; Kanlayavattanakul, M. Hair loss and herbs for treatment. J. Cosmet. Dermatol. 2013, 12, $210-212$. [CrossRef]

98. Fischer, T.W.; Hipler, U.C.; Elsner, P. Effect of caffeine and testosterone on the proliferation of human hair follicles in vitro. Int. J. Dermatol. 2007, 46, 27-35. [CrossRef]

99. Esfandiari, A.; Kelley, P. The effects of tea polyphenolic compounds on hair loss among rodents. J. Natl. Med. Assoc. 2005, 97, 816-818.

100. Hiipakka, R.A.; Zhang, H.Z.; Dai, W.; Dai, Q.; Liao, S. Structure-activity relationships for inhibition of human $5 \alpha$-reductase by polyphenol. Biochem. Pharmacol. 2002, 63, 1165-1176. [CrossRef]

101. Satoh, K.; Sakamoto, Y.; Ogata, A.; Nagai, F.; Mikuriya, H.; Numazawa, M.; Yamada, K.; Aoki, N. Inhibition of aromatase activity by green tea extract catechins and their endocrinological effects of oral administration in rats. Food Chem. Toxicol. 2002, 40, 925-933. [CrossRef]

102. Kwon, O.S.; Han, J.H.; Yoo, H.G.; Chung, J.H.; Cho, K.H.; Eun, H.C.; Kim, K.H. Human hair growth enhancement in vitro by green tea epigallocatechin-3-gallate (EGCG). Phytomed 2007, 14, 551-555. [CrossRef] [PubMed]

103. Rothenberger, J.; Krauss, S.; Tschumi, C.; Rahmanian-Schwarz, A.; Schaller, H.E.; Held, M. The effect of polyhexanide, octenidine dihydrochloride, and tea tree oil as topical antiseptic agents on in vivo microcirculation of the human skin: A noninvasive quantitative analysis. Wounds 2016, 28, 341-346.

104. Conney, A.H.; Kramata, P.; Lou, Y.R.; Lu, Y.P. Effect of caffeine on UVB-induced carcinogenesis, apoptosis, and the elimination of UVBinduced patches of p53 mutant epidermal cells in SKH-1 mice. Photochem. Photobiol. 2008, 84, 330-338. [CrossRef]

105. Cameron, O.G.; Modell, J.G.; Hariharan, M. Caffeine and human cerebral blood flow: A positron emission tomography study. Life Sci. 1990, 47, 1141-1146. [CrossRef]

106. Okuno, T.; Sugiyama, T.; Tominaga, M.; Kojima, S.; Ikeda, T. Effects of caffeine on microcirculation of the human ocular fundus. Jpn. J. Ophthalmol. 2002, 46, 170-176. [CrossRef]

107. Lupi, O.; Semenovitch, I.J.; Treu, C.; Bottino, D.; Bouskela, E. Evaluation of the effects of caffeine in the microcirculation and edema on thighs and buttocks using the orthogonal polarization spectral imaging and clinical parameters. J. Cosmet. Dermatol. 2007, 6, 102-107. [CrossRef]

108. Yanagida, A.; Shoji, A.; Shibusawa, Y.; Shindo, H.; Tagashira, M.; Ikeda, M.; Ito, Y. Analytical separation of tea catechins and food-related polyphenols by high-speed counter-current chromatography. J. Chromatogr. A 2006, 1112, 195-201. [CrossRef]

109. Zillich, O.V.; Schweiggert-Weisz, U.; Hasenkopf, K.; Eisner, P.; Kerscher, M. Release and in vitro skin permeation of polyphenols from cosmetic emulsions. Int. J. Cosmet. Sci. 2013, 35, 491-501. [CrossRef]

110. Van de Sandt, J.J.; Van Burgsteden, J.A.; Cage, S.; Carmichael, P.L.; Dick, I.; Kenyon, S.; Korinth, G.; Larese, F.; Limasset, J.C.; Maas, W.J.; et al. In vitro predictions of skin absorption of caffeine, testosterone, and benzoic acid: A multi-centre comparison study. Regul. Toxicol. Pharmacol. 2004, 39, 271-281. [CrossRef]

111. Zesch, A.; Schaefer, H.; Stuttgen, G. The quantitative distribution of percutaneously applied caffeine in the human skin. Arch. Dermatol. Res. 1979, 266, 277-283. [CrossRef] [PubMed]

112. Touitou, E.; Levi-Schaffer, F.; Dayan, N.; Alhaique, F.; Riccieri, F. Modulation of caffeine skin delivery by carrier design: Liposomes versus permeation enhancers. Int. J. Pharm. 1994, 103, 131-136. [CrossRef] 
113. Mustapha, R.B.; Lafforgue, C.; Fenina, N.; Marty, J. Influence of drug concentration on the diffusion parameters of caffeine. Indian J. Pharmacol. 2011, 43, 157-162. [CrossRef]

114. Shakeel, F.; Ramadan, W. Transdermal delivery of anticancer drug caffeine from water in- oil nanoemulsions. Colloids Surf. B Biointerfaces 2010, 75, 356-362. [CrossRef] [PubMed]

115. Bourgeois, S.; Bolzinger, M.A.; Pelletier, J.; Valour, J.P.; Briançon, S. Caffeine microspheres-an attractive carrier for optimum skin penetration. Int. J. Cosmet. Sci. 2010, 32, 318-321. [CrossRef]

116. Możdżeń, K.; Barabasz-Krasny, B.; Szymacha, K.; Oliwa, J. The plant used in the cosmetic masks. Pol. J. Cosmetol. 2016, 19, 372-379.

(c)

(C) 2019 by the authors. Licensee MDPI, Basel, Switzerland. This article is an open access article distributed under the terms and conditions of the Creative Commons Attribution (CC BY) license (http://creativecommons.org/licenses/by/4.0/). 